Working Paper No. 641, 2005

\title{
Asymmetric Effects of Corruption on FDI: Evidence from Swedish
} Multinational Firms

by Katariina Hakkala, Pehr-Johan Norbäck and Helena Svaleryd

IUI, The Research Institute of Industrial Economics

P.O. Box 5501

SE-114 85 Stockholm

Sweden 


\title{
Asymmetric Effects of Corruption on FDI:
}

\section{Evidence from Swedish Multinational Firms*}

\author{
Katariina Hakkala†, Pehr-Johan Norbäck ${ }^{\ddagger}$ and Helena Svaleryd ${ }^{\S}$
}

\begin{abstract}
We examine the effect of corruption on foreign direct investments (FDI). Starting out from the theory of FDI, we show that corruption can have different effects on horizontal investments, which are primarily aimed at sales to the local market, compared to vertical investments, which are made to access lower factor costs for export sales. Using Swedish firm-level data, we find that corruption reduces the probability that a firm will invest in a country. Moreover, when studying the different types of investments, we find that horizontal
\end{abstract}

*We thank the referee, Jonas Vlachos, and seminar participants at the Research Institute of Industrial Economics, the Stockholm University, the SAET conference in Vigo, the ETSG conference in Nottingham and the EEA conference in Madrid for comments. We also thank Jörgen Nilsson for excellent research assistance and Mark Blake for editorial assistance. Financial support from the Marianne and Marcus Wallenberg Foundation and Jan Wallander's and Tom Hedelius' Research Foundations is gratefully acknowledged.

†The Research Institute of Industrial Economics (IFN), P.O. Box 55665, SE-102 15 Stockholm, Sweden, phone +46-8-665 4534. E-mail Katariina.Hakkala@ifn.se

$\ddagger$ The Research Institute of Industrial Economics (IFN), P.O. Box 55665, SE-102 15 Stockholm, Sweden, phone +46-8-665 4522. E-mail Pehr-Johan.Norback@ifn.se

§The Research Institute of Industrial Economics (IFN), P.O. Box 55665, SE-102 15 Stockholm, Sweden, phone +46-8-665 4529. E-mail Helena.Svaleryd@ifn.se 
investments, measured by affiliate local sales, are to a larger extent than vertical investments deterred by corruption. We are also able to establish a causal effect of corruption on FDI.

Keywords: FDI, corruption, multinational firm

JEL classification: D73, F21, F23 


\section{Introduction}

In the public debate, corruption is generally portrayed as an important barrier to foreign direct investments (FDI), with a negative effect on the business environment. Economic theory offers several mechanisms to explain why corruption is detrimental to investments. Corruption may effectively act as a tax on investments, or increase insecurity about costs and thereby deter foreign direct investments (e.g. Shleifer and Vishny, 1993, and Wei, 1997). On the other hand, it has also been suggested that bribery may be an efficient way of circumventing regulations and inefficient legal systems and may, in fact, help foreign investors to enter a market (e.g. Lui, 1985, and the discussion in Bardhan, 1997).

In this paper, we re-examine the relationship between foreign direct investments and corruption. The previous empirical evidence generally suggests that corruption has a negative effect on aggregate investment flows (e.g. Wei, 2000 and Hines, 1995). Due to the nature of aggregated data used in these studies, they are not able to uncover how corruption affects individual firm behavior. We provide new evidence by analyzing how corruption impacts both firms' decision to invest and the size of different activities of their foreign affiliates. For this purpose, we use unique firm-level data on Swedish multinational enterprises (MNEs).

In the FDI literature, a difference is usually made between two broad types of FDI: horizontal and vertical. The main purpose of horizontal FDI is to obtain better market access to local markets within a host country. Vertical FDI, on the other hand, are made primarily to access lower production costs and to produce inputs or final goods for export 
to destinations outside the host country. Our contribution is to show, both theoretically and empirically, that corruption can impact these distinct types of FDI differently.

In the empirical analysis, we first examine how corruption affects a firm's decision to invest in a host country. Given the investment choice, we then examine how measures of affiliate activity, which are closely linked to the different types of FDI, are affected by corruption. We split total affiliate sales into three sub-components: local sales to the host-country market, exports back to the home country and exports to third countries, measuring horizontal, vertical and export-platform FDI, respectively. Using firm-level data on Swedish multinational enterprises and a host of control variables associated with explaining FDI, we find that corruption lowers the probability of a firm investing in a country. We establish that the effect is causal by employing an instrumental variable approach. Furthermore, given that an investment takes place, we find that corruption mainly decreases local affiliate sales, while having no robust impact on either affiliate exports to Sweden or exports to third country markets. For the two types of affiliate export sales, we find a positive impact of corruption in simple OLS regressions. However, when controlling for endogeneity and sample selection bias, there is no robust impact of corruption on affiliate export sales.

Our results suggest that corruption mainly deters horizontal FDI, i.e. market seeking investments. A simple model shows that this is consistent with corruption increasing marginal costs for affiliate production for the local market, while having no effect on affiliate production for export markets. This may be the case, since producing and selling to the local market entail greater engagement with public officials in the country where 
corruption is present. For instance, Svensson (2003) finds that Ugandan firms receiving public services are more likely to have to pay bribes.

We also present some results indicating that firm characteristics influence the impact of corruption on FDI: both the probability of investing in a country, and the size of the investment. In particular, R\&D-intensive firms are less deterred by corruption when deciding whether to invest. Given that $R \& D$ intensity translates into more power to refuse to pay bribes, this suggests that the bargaining power of a firm influences the cost of corruption. This result is in line with Svensson (2003), who shows that public officials demand less bribes from firms with greater bargaining strength.

Our study builds on previous empirical studies investigating the effect of corruption on FDI. A majority of these studies analyzes aggregate investment flows. For example, Wei (2000) examines the effect of taxation and corruption on FDI using a sample covering bilateral stocks of FDI. He shows that an increase in the tax rate or level of corruption reduces inward foreign direct investment. In another study Wei (1997), he argues that the negative impact of corruption mainly stems from the corruption-induced uncertainty on FDI. Negative effects are also found in Hines (1995), who studies how a law criminalizing bribery to foreign officials affects investments from U.S. multinational firms. An exception from these studies is Smarzynska and Wei (2000) who use firm-level data for investments in Eastern Europe and the former Soviet Union. They show that corruption in a host country reduces the probability of an inward investment and that the host country's level of corruption affects the firm's investment mode. Corruption shifts the ownership structure of FDI from wholly-owned investments to joint ventures with local partners, indicating 
that firms need a local partner to invest in a country where corruption is prevalent. Their firm-level data makes it possible to study the probability of a firm investing, but does not allow for disentangling possible asymmetric effects in terms of the impact of corruption on different types of affiliate activities.

Some limitations of our analysis should be mentioned. While we have very detailed firm-level and affiliate-level information on Swedish MNEs, in terms of variables such as R\&D or sales flows, our corruption measure builds on different types of available indices. As noted by Wei (2000), these provide less detailed information than is used in models of corruption, such as Shleifer and Vishny (1993), and in the theoretical framework employed here.

This paper is structured as follows: Section 2 includes the model showing that the effects of corruption on different investment flows may be asymmetric. Section 3 covers the empirical model and the choice of proxies and the data. The results are presented in Section 4 and Section 5 concludes.

\section{Corruption and FDI - A Theoretical Framework}

In this section we will show that corruption can have asymmetric effects on foreign direct investment (FDI). First, the impact can differ for a MNE's investment and sales decisions. Second, corruption can have different effects on different types of affiliate sales activities. In order to highlight these effects, we provide a sparse model of FDI taking corruption as exogenous. It is then straightforward to extend the model to endogenize corruption and 
enrich the description of the investment decisions taken by MNEs. ${ }^{1}$

Consider a (potentially) multinational firm (MNE), which sells a good in two segmented markets: its non-corrupt home country, labeled Country $\mathcal{H}$, and in a foreign corrupt Country, labeled Country $\mathcal{F}^{2}$ The MNE is the sole producer of this good and thus has monopoly power in each market. The interaction is as follows: in stage one, the MNE chooses whether to invest in a plant in Country $\mathcal{F}$ at a fixed cost. Due to corruption, the firm must also pay bribes to a corrupt official. Without bribing, the MNE cannot invest because the official can otherwise stall or terminate the investment. ${ }^{3}$ In stage two, product market interaction takes place.

If the MNE invests in Country $\mathcal{F}$, all production is offshored to the foreign plant. To ensure this, Country $\mathcal{F}$ has prohibitive tariffs on imports ruling out direct exports as an alternative for the MNE to serve this market. ${ }^{4}$ Production costs in Country $\mathcal{F}$ are also lower than in Country $\mathcal{H}$, while Country $\mathcal{H}$ has zero tariffs on imports, providing an incentive to offshore the production sold on the home market. Referring to the theoretical literature on FDI, the MNE has a horizontal motive, through establishing market access (by avoiding the trade costs in Country $F$ when producing and selling locally), as well as a vertical motive to reduce production costs (by relocating production to foreign Country $\mathcal{F}$ with lower production costs and exporting back to the home market in Country $\mathcal{H})$.

When investing in Country $\mathcal{F}$, the affiliate of the MNE generates two types of sales: affiliate local sales $(\mathrm{L})$ in Country $\mathcal{F}$, denoted $q_{L}$, and affiliate exports $(\mathrm{E})$ back to Country $\mathcal{H}$, denoted $q_{E}$. Let $\pi_{L}=\left[P_{\mathcal{F}}\left(q_{L}\right)-c_{L}\right] q_{L}$ be the variable profit from affiliate local sales and 
let $\pi_{E}=\left[P_{\mathcal{H}}\left(q_{E}\right)-c_{E}\right] q_{E}$ be the variable profit from affiliate exports, where the marginal costs of producing in Country $\mathcal{F}$ for local sales in Country $\mathcal{F}$ is $c_{L}$ and the marginal cost of production for affiliate exports to Country $\mathcal{H}$ is $c_{E}$. Omitting the country index, let the inverse demand curve in each country fulfill $P^{\prime}<0$ and $P^{\prime \prime} \leq 0$.

Let us now discuss in which ways corruption will impact FDI. The most common form of corruption met directly by businesses is financial corruption in the form of demands for special payments and bribes connected with import and export licenses, exchange controls, tax assessments, police protection or other public services. Such corruption implies additional costs for a firm in the form of bribes, but may also be cost-reducing given that bribing leads to advantages such as a preferential tax treatment, reduced costs for licenses and permits, or faster handling of bureaucratic procedures. While corruption may reduce some costs in principle, it seems that most studies on the micro-level show that corruption increases costs for firms. For example, by using survey data on Ugandan firms, Svensson (2003) finds that firms engaged in trade, receiving public services and paying several types of taxes face a higher probability of having to pay bribes. The findings of Svensson suggest that firms have to pay when dealing with public officials whose actions could have large effects on business operations. However, multinational firms may be less affected by corruption than indigenous firms. For instance, some developing countries offer foreign firms special treatment in terms of lower start-up costs and tax breaks to attract FDI. Local officials may also have less bargaining power over multinationals, since multinationals have better outside options and can use laws in their home countries as a binding constraint of the bribe they offer. ${ }^{5}$ 
To generate testable predictions on how corruption affects a firm's decision to invest in a country, we take a general approach and examine the investment decisions for a variety of ways in which corruption may affect firm's costs. Thus, assume that a MNE's marginal costs when producing in Country $\mathcal{F}, c_{L}$ and $c_{E}$, as well as the the fixed investment cost, denoted $G$, will depend on the level of corruption in Country $\mathcal{F}, \varphi_{\mathcal{F}}$. We can then write $c_{L}\left(\varphi_{\mathcal{F}}\right), c_{E}\left(\varphi_{\mathcal{F}}\right)$ and $G\left(\varphi_{\mathcal{F}}\right)$

The optimal sales in stage 2, given that FDI is chosen in stage 1 , are defined from the first-order conditions $\partial \pi_{L}\left(q_{L}^{*}\right) / \partial q_{L}=0$ and $\partial \pi_{E}\left(q_{E}^{*}\right) / \partial q_{E}=0$, assuming that the second-order conditions are fulfilled. Optimal sales in each market can be written in reduced-form function as $q_{L}^{*}\left(\varphi_{\mathcal{F}}\right)$ and $q_{E}^{*}\left(\varphi_{\mathcal{F}}\right)$. Reduced-form variable profits for the MNE when investing are then $\pi_{L}^{*}\left(\varphi_{\mathcal{F}}\right)=\left[P_{\mathcal{F}}\left(q_{L}^{*}\left(\varphi_{\mathcal{F}}\right)\right)-c_{L}\left(\varphi_{\mathcal{F}}\right)\right] q_{L}^{*}\left(\varphi_{\mathcal{F}}\right)$ for affiliate local sales and $\pi_{E}^{*}\left(\varphi_{\mathcal{F}}\right)=\left[P_{\mathcal{H}}\left(q_{E}^{*}\left(\varphi_{\mathcal{F}}\right)\right)-c_{E}\left(\varphi_{\mathcal{F}}\right)\right] q_{E}^{*}\left(\varphi_{\mathcal{F}}\right)$ for affiliate export sales.

Turning to stage 1, it follows that the total profit for the MNE when investing in Country $\mathcal{F}$ is:

$$
\Pi^{F D I}\left(\varphi_{\mathcal{F}}\right)=\pi_{L}^{*}\left(\varphi_{\mathcal{F}}\right)+\pi_{E}^{*}\left(\varphi_{F}\right)-G\left(\varphi_{F}\right)
$$

Let $\bar{\pi}$ denote the profit for the MNE when not investing in the corrupt market $\mathcal{F}$. Thus, $\bar{\pi}$ is the profit from only producing and selling in its non-corrupt home market $\mathcal{H}$. It then follows that in order to invest in Country $\mathcal{F}$ in stage 1, total profits from investing must be higher than the profit of not investing, $\Pi^{F D I}\left(\varphi_{\mathcal{F}}\right)>\bar{\pi}$. 
Let us now discuss how corruption may affect the MNE's investment in stage 1 and sales decisions in stage 2. Differentiating $\Pi^{F D I}$ in corruption $\varphi_{F}$ and using the envelope theorem gives:

$$
\frac{d \Pi^{F D I}}{d \varphi_{\mathcal{F}}}=\underbrace{-c_{L}^{\prime}\left(\varphi_{\mathcal{F}}\right) q_{L}^{*}}_{\text {Affiliate local sales }}-\underbrace{c_{E}^{\prime}\left(\varphi_{\mathcal{F}}\right) q_{E}^{*}}_{\text {Affiliate Exports }}-\underbrace{G^{\prime}\left(\varphi_{\mathcal{F}}\right)}_{\text {Net fixed cost }}
$$

Expression (2.2) can now be used to illustrate how corruption may have an asymmetric effect on a firm's investment decisions. Several things can be noted.

First, corruption may have different impacts on the MNE's discrete investment decision and affiliate sales decisions. To see this, let $c_{L}^{\prime}\left(\varphi_{\mathcal{F}}\right)=c_{E}^{\prime}\left(\varphi_{\mathcal{F}}\right)=0$ and $G^{\prime}\left(\varphi_{\mathcal{F}}\right)>0$ hold in (2.2). Since paying bribes increases the MNE's fixed cost of investment without affecting its production costs, an investment is less likely but, given an investment, corruption has no effect on affiliate sales.

Second, corruption may affect the composition of affiliate sales. For instance, producing for the local market may imply a greater exposure to corruption, if it requires greater involvement with public officials. To see this, let $c_{L}^{\prime}\left(\varphi_{\mathcal{F}}\right)>0=c_{E}^{\prime}\left(\varphi_{\mathcal{F}}\right)$ and $G^{\prime}\left(\varphi_{\mathcal{F}}\right)>0$ hold in (2.2). Affiliate profits generated from export sales would then be unaffected by corruption, whereas profits from affiliate local sales would decrease, since $d \pi_{L}^{*}\left(\varphi_{\mathcal{F}}\right) / d \varphi_{\mathcal{F}}=$ $-c_{L}^{\prime}\left(\varphi_{\mathcal{F}}\right) q_{L}^{*}<0$. The MNE would react by reducing its affiliate local sales $q_{L}^{*}$, while affiliate export sales $q_{E}^{*}$ would be unaffected. From (2.2), an investment would also be less likely.

Third, export activities with destination markets outside the host country may have a 
lower degree of involvement in the local economy. Production costs of export sales may in fact decrease, for example, due to a tax relief. Assuming $c_{E}^{\prime}\left(\varphi_{\mathcal{F}}\right)<0<c_{L}^{\prime}\left(\varphi_{\mathcal{F}}\right)$, affiliate export sales $q_{E}^{*}$ would increase since $d \pi_{E}^{*}\left(\varphi_{\mathcal{F}}\right) / d \varphi_{\mathcal{F}}=-c_{E}^{\prime}\left(\varphi_{\mathcal{F}}\right) q_{E}^{*}>0$, while affiliate local sales decrease. Corruption would in this example benefit the vertical component of affiliate sales, while having a negative impact on the horizontal component. The total effect of corruption on the investment decision in stage 1 would therefore be ambiguous and determined by the relative size of the vertical and horizontal sales activities, as captured by the weights $q_{E}^{*}$ and $q_{L}^{*}$ in $(2.2)$.

Finally, we should note that if the MNE faced competition by indigenous firms in Countries $\mathcal{H}$ and $\mathcal{F},(2.2)$ would be augmented by strategic effects due to oligopoly interaction. This gives rise to a set of additional predictions, which are described in greater detail in Hakkala et al (2005). We now turn to the empirical analysis.

\section{Econometric Analysis}

The theoretical framework suggests that corruption can have asymmetric effects on different types of investment flows. In the econometric analysis, we will study the impact of corruption on both the probability of a firm investing, and the level of different types of affiliate activities, by using a sample of Swedish multinational firms. 


\subsection{Econometric Model}

In the first empirical model, we study the effect of corruption on firms' decisions to invest in a country by estimating the likelihood of a country receiving investments from our sample firms:

$$
\begin{aligned}
& D F D I_{i j}=\alpha_{0}+\alpha_{1} \text { Corruption }_{j}+\boldsymbol{\alpha}_{2}^{\prime} \mathbf{x}_{i}+\boldsymbol{\alpha}_{3}^{\prime} \mathbf{x}_{j}+\varepsilon_{i j} \\
& \text { where: } \begin{cases}D F D I_{i j}=1 & \text { if the firm } i \text { has FDI in country } j \\
D F D I_{i j}=0 & \text { otherwise, }\end{cases}
\end{aligned}
$$

where $\mathbf{x}_{i}$ is a vector of the firm-specific variables, $\mathbf{x}_{j}$ is a vector of the country-specific variables and $\varepsilon_{i j}$ is the usual error term. Corruption enters as a country-specific factor influencing the firms' choice of host countries.

In the second empirical model, we estimate, using a log-linear gravity equation, the effect of corruption on different types of affiliate sales given that investment has taken place. For firm $i$, with affiliate sales in host country $j, q_{i j}$, we have:

$$
q_{i j}=\beta_{0}+\beta_{1} \text { Corruption }_{j}+\boldsymbol{\beta}_{2}^{\prime} \mathbf{x}_{i}+\boldsymbol{\beta}_{3}^{\prime} \mathbf{x}_{j}+u_{i j}
$$

where $\mathbf{x}_{i}$ and $\mathbf{x}_{j}$ are defined as above, and $u_{i j}$ is the usual error term. All variables in (3.1) and (3.2), except corruption, are defined in logs and all specifications use clustered standard errors since country-specific variables are repeated over firms. Corruption is 
proxied by index variables. We discuss the other firm- and country-specific factors affecting FDI, the choice of proxies and the data in the sections below. Correlation tables, a detailed description of the variables used and data sources are presented in the Appendix.

\subsection{Dependent Variables}

We use data for Swedish multinational firms in manufacturing industries, compiled by the Research Institute of Industrial Economics (IFN). The data has been collected from a questionnaire sent to all Swedish MNEs and approximately every fourth year since the 1970s. The survey covers almost all Swedish multinational firms in the manufacturing sector, their producing affiliates abroad, and detailed information on variables such as R\&D, employment, production and internal and external trade flows. ${ }^{6}$ Here, we mainly use data for 1998 and thus focus on a cross-section analysis. The primary reason is that the corruption measures are only available from the mid 1980s and show very little variation over time. In spite of this, however, we will in section 4.3 use panel data to exploit the time variation.

To study the impact of corruption on the probability that a firm will invest, we create a dummy indicating that the firm is producing in the country. Our measure of total sales is the sum of all affiliates' local production for each country. Thus, every firm in our sample will correspond to one observation for each country, even though they may have several affiliates located in the country. Following the predictions from our stylized model, we decompose total affiliate sales into affiliate local sales to the host-country market, affiliate 
exports back to Sweden and affiliate exports to third countries. ${ }^{7}$ Following Braconier et al (2005), these different categories can broadly be considered as vertical, horizontal and export platform FDI. The third category is defined by the recent theories on FDI that expand the standard two-country models to include more countries. We expect that both the closeness to large neighboring markets and possible cost advantages are motives of this type of investment and that the effect of corruption on exports to third markets is similar to that of corruption on exports to the home market. ${ }^{8}$ The largest part of affiliate sales is sales to the local market (55 percent of total sales), the second largest is exports to third markets (35 percent of total sales) while the smallest category is sales back to Sweden (10 percent of total sales). ${ }^{9}$

We use all four affiliate sales measures to estimate the OLS regression (3.2). In the probit estimation (3.1), the dependent variable takes on the value of one if a firm has an affiliate in the host country, and zero otherwise.

\subsection{Measuring Corruption}

In the theoretical model, corruption is modelled as a potential cost on production. However, the available cross-country measures of corruption do not directly capture costs of corruption. Our primary measure of corruption is from the International Country Risk Group (ICRG). The measure is an assessment of corruption within the country's political system, which may be a threat to foreign investment since it distorts the economic and financial environment and reduces the efficiency of government and business. The ICRG 
measure is preferred to other corruption measures because of its widespread country coverage. Like other available measures corruption, ICRG is based on subjective observations and/or surveys of respondents. The higher the ICRG index value, the less corrupt the country. For expositional reasons, we invert the measure to derive an index that increases with corruption. ${ }^{10}$ For robustness, we also use another measure of corruption, the Transparency International Corruption Perception Index (TI). The TI is a composite index, making use of several surveys of business people and assessments of country analysts.

Table 1 lists all countries included in the sample, their levels of corruption, the number of firms producing in the countries and the sum of investment from our sample of firms in $1998 .{ }^{11}$ Furthermore, we also calculate the average share of production sold on the local market for each country. 65 countries are included in our sample, where the choice of countries is determined by the availability of the corruption measure and our control variables (described in the next section). Table 1 does not reveal a clear-cut relationship between FDI and corruption. Looking at the end with a high level of corruption, it is true that these countries receive fewer, if any, investments. For instance, countries with 1-3 investing firms have on average higher level of corruption than countries with more than 10 investing firms. However, this may simply reflect the low development level in the former group.

[Table 1 here] 


\subsection{Additional Explanatory Variables}

The theoretical framework in Section 2 can be extended to incorporate a number of factors influencing FDI. We do not pursue this here, but rather follow literature on FDI in order to identify additional factors that affect FDI in general, and different types of investment in particular. The theory on FDI suggests that host country market size should increase horizontal investments, while being less important for vertical investments. ${ }^{12}$ As can be verified in our theoretical framework, a large host market size should increase affiliate local sales, while affiliate sales back to Sweden should be less affected. We use two proxies of market size: gross domestic production of the host country $(G D P)$, and a measure of market potential in the neighboring countries (Market pot.) developed by Harris (1954) and based on data on gross domestic production. ${ }^{13}$ The latter is mainly hypothesized to increase affiliate sales to third countries.

Factor costs are expected to be most important for vertical FDI, and hence affect affiliate exports most. Data for labor costs is not available for a large sample of countries and we therefore proxy factor cost differentials by endowments of labor with primary or secondary education (Labor). More specifically, the measure of labor endowments is the percentage of the population aged 25 and above that has primary or secondary education in 1999. We also include GDP per capita (GDP / capita) as a measure of labor productivity and general level of development. While having a smaller country coverage, we also make use of a direct measure for labor costs, the hourly wage cost of a toolmaker (Wage costs). Wage costs are from the Union Bank of Switzerland (UBS), and have previously been used 
in Braconier et al. (2005).

We will take into account plant- and firm-level economics of scale and trade costs since the previous literature has suggested them to be important determinants of FDI. Recent theory also shows that firm heterogeneity plays a role in explaining FDI (Helpman, Melitz and Yeaple, 2004). Firm-level scale economies are likely to promote FDI, while plant-level economies of scale promote the concentration of activity and discourage the break up of production into several plants. Plant-scale economies in the industry of the FDI activity (Scale) is defined as the average plant-level sales in four-digit industries according to the Swedish Industry Classification (SNI). As a proxy for firm-level scale economies, we use the size of the firm in terms of total sales (Size). We also include R\&D expenditure in the total sales of the firm $(R \mathscr{E} D)$. R\&D is identified as a firm-specific asset typically promoting FDI. However, this might not be the case among firms having already decided to produce abroad. An explanation is that technology transfer costs may be detrimental, particularly for horizontal FDI (Norbäck, 2001).

We consider two components of trade costs: trade barriers and transportation costs. A greater circle distance between Sweden and a foreign country is used to proxy transportation costs (Distance). Distance is typically included in gravity models explaining the geographical pattern of trade, but it has also been found to have a negative effect on FDI (e.g. Ekholm, 1998). Distance may proxy other barriers, including cultural differences in addition to transportation costs. To construct measures of trade barriers, we use data on tariffs produced by UNCTAD. ${ }^{14}$ Tariffs are hypothesized to deter sales back to Sweden, since they increase costs, but to increase investments for local sales, since the motive for 
investment may be tariff-jumping. We aggregate tariffs differently, depending on the type of investment (Tariff_hor, Tariff_ver and Tariff_plat). ${ }^{15}$ Tariffs on exports to the home country are defined as those that firms encounter when exporting from the host country to Sweden (Tariff_ver). Tariffs affecting sales to the host market are the tariffs on exports from Sweden to the foreign country, since local sales are regarded as a substitute for exports from the home country (Tariff_hor). Finally, a firm producing abroad and exporting to a third country is affected by tariffs encountered in the third country. Since the third country, to which the exports are destined, is not reported by the affiliate firms, we compute aggregate tariffs encountered by the host country in the rest of the world (Tariff_plat).

In Section 2, corruption is hypothesized to affect production costs in the host country. To isolate the effect of corruption, we need to control for other host country specific factors determining costs. One factor that may be important for the firm's investment choice is local taxes. That taxes are important has been shown by, for example, Wei (2000) who finds host country taxes deter aggregate investment. Furthermore, Mutti and Gruber (2004) show that taxes can have asymmetric effects on FDI, with larger negative effects on investments geared toward export markets than other types of investment. We use the average corporate tax rate on profits $(\operatorname{Tax})$ as a measure of tax. Another factor is the cost of investing in a country due to regulation. Although this is not easily measured, we make use of measures of the cost of entry presented in Djankov et. al. (2002). Time is the official time it takes to start-up a new firm in the country. As a robustness check, we include electricity consumption per capita (Electricity) as a proxy for the quality of the 
infrastructure, since it may also affect local production costs.

Another country characteristic that may have an impact on inward FDI is the existence of export processing zones, where firms are offered free trade conditions and a liberal regulatory environment, often including generous tax concessions. To control for this, we use a dummy variable to indicate whether a country has any export processing zones $(E P Z)$. Finally, we use region dummy variables based on free trade agreements, capturing ASEAN, EU/EFTA, NAFTA and MERCOSUR.

A major problem with our measures of corruption is that they are subjective indices. It is possible that, in fact, they measure not only corruption, but the general level of institutional quality in the country. To control for this, we use other indices from the International Country Risk Guide. These measure the general investment climate in the country (Invest risk), respect for law and order and bureaucracy quality. As expected, these measures are highly correlated with our measures of corruption.

\section{Results}

\subsection{Corruption and Investments}

First, we turn to the question of whether corruption affects the probability of a firm investing in a country by estimating equation (3.1). The results are shown in Table 2. As can be seen in the first column, corruption has a negative impact on the FDI decision when controlling for other important factors. Our result is in line with Smarzynska and 
Wei (2000), who also find that corruption reduces the probability that a firm will invest.

The next four columns show the results from estimating equation (3.2) for levels of four different FDI measures: total affiliate sales, local sales, exports to Sweden, and exports to third countries. There is no effect of corruption on total sales. However, dividing the sample into different types of sales reveals that the effect of corruption varies depending on the type of FDI. Corruption significantly decreases local sales, but actually increases exports to Sweden and sales to third countries.

Turning to control variables, the size of the foreign market attracts investments and is, as predicted, important for investment aimed at sales to the local market. Proximity to other larger markets (Market Pot) has no effect on the probability that the firm will invest, but, as expected, it increases sales to third countries. Our tax measure is surprisingly positively correlated with the probability of a firm investing in a particular country, but there is no effect on the level of sales.

Distance to Sweden deters investments, as do the tariffs Sweden imposes on imports from a particular country. The last result is supportive of the view that firms, at least to some extent, invest abroad in order to sell back to Sweden. The share of the labor force which has low or medium level of education is only positively correlated with the investments aimed at sales back to Sweden. The result indicates low labor costs being important, consistent with the idea that production costs are a major driving force of vertical investments. Firms in industries with large plant-level economies of scale are less prone to make FDI, but have larger sales after investment. As is often found in studies 
on FDI, the size of the firm is important for the decision to invest. Interestingly, R\&Dintensive firms seem to be less prone to invest and the level of local sales is also lower for these firms. The result is in line with Norbäck (2001), who interprets the negative relationship as evidence of high technology transfer costs, discouraging foreign production. After controlling for an extensive list of factors explaining FDI, GDP per capita has little impact on FDI. Only investments aimed at sales to third countries are positively correlated with GDP/ capita. Finally, export processing zones (EPZ) are negatively correlated with the probability of an investment, but seem, as expected, to encourage production for sales to third countries.

All in all, the results for our control variables give support for dividing up the total sales into the following categories: local sales (primary driven by horizontal motives), sales back to Sweden (primary driven by vertical motives), and sales to third countries (primary driven by export-platform motives).

[Table 2 here]

\subsection{Selection Problems and Omitted Variables}

The results indicate that there are asymmetric effects of corruption on FDI. Corruption decreases the probability that a firm invests in a host country. Furthermore, corruption decreases affiliate local sales, but increases affiliate exports. The first two results are consistent with the previous literature on FDI and corruption, while the third is not. The 
latter result is consistent with the idea that corruption provides an advantage by lowering the production costs of a MNE when exporting to external markets, as discussed in the theoretical framework in Section 2. To analyze whether this is the case, we will scrutinize the empirical result thoroughly here.

The primary concern is that these results may be driven by a selection bias and/or omitted variables. Selection could result in upward biased estimates if countries with large investments are selected due to, for example, low production costs, and low production costs and corruption are positively correlated. The selection bias would then lead to overestimation of the positive effect of corruption on sales back to Sweden, and underestimation of the negative effect on local sales.

In the case of omitted variables, our primary concern is that low labor costs are correlated with corruption. If we fail to control for labor costs, corruption may only reflect that vertical FDI is primarily driven by access to cheap labor. While including our measure on labor endowments and GDP per capita in all specifications should control for the effect of labor costs, we also conduct further checks as described below. Another concern is that corruption is picking up the effect of other country-specific institutional factors. To check the robustness of our results to the omitted variables problem, we use additional measures of labor costs and institutional quality.

Table 3 shows the results when controlling for selection bias using the Heckman procedure. In the selection stage, we use all control variables, since the firm's decision to invest depends on the profitability of all different types of affiliate activities. In the estimation of 
the level of different types affiliate sales, however, we only include the variables affecting the specific type of affiliate activity. ${ }^{16}$ For instance, when studying the impact of corruption on local sales, in addition to tariff_hor we also include tariff_plat and tariffs_ver in the selection step, but not in the level estimation, where we only use tariff_hor.

The effect of corruption on the probability of an investment taking place is negative and statistically significant for all types of investment, except for investments aimed at export sales back to Sweden. Interestingly, the results clearly indicate that there is a selection problem and that estimates in Table 2 were upward biased. The estimated negative coefficient of corruption on local sales is larger than in Table 2 and the estimate of corruption on export sales back to Sweden is no longer statistically significant. The coefficients on the control variables remain largely the same. Once we have taken into account the selection bias by Heckman two-step procedure, we still find an asymmetric impact of corruption on horizontal FDI (measured as local sales), vertical FDI (measured as sales back to Sweden) and export-platform FDI (measured as sales to third countries).

Similar to Wei (2000), we find that the estimates produce surprisingly large effects. An increase in the level of corruption equivalent to one grade in the ICRG measure from zero to six is associated with a 32 percent increase in exports to third countries, and a 24 percent decrease in local sales. ${ }^{17}$ In the selection stage, an equivalent increase in the ICRG measure reduces the likelihood that an investment will take place with 16 percent. Hence, when aggregating the negative effect of corruption on local sales and the positive effect of corruption on export sales, these roughly cancel out. This is also consistent with the negative, but not statistically significant, point estimate of corruption on total sales 
in the second column of Table 2.

[Table 3 here]

The question that remains is whether the different effects are a result of omitted variables. Table 4 presents the results from estimations including possible omitted factors. The top half of the table shows the results when using our other, more direct, measure of wage cost, the hourly wage cost of a toolmaker. According to the results, high wage costs have no impact on the probability that a firm will invest in a country, but do reduce the level of investment. Although this is true for both investments aimed at selling the local market and back to Sweden, the effect is, as expected, larger for investments aimed at selling back to Sweden.

Next, we include Invest risk measuring the investment climate in the host country and Time proxying the bureaucratic cost of setting up a new firm, to rule out that we are picking up effects of other institutions with our corruption measure. The results in the lower half of Table 4 show that corruption is still strongly negatively correlated with the probability that a firm will invest in a country. Moreover, sales to the local market are to a higher extent negatively affected by corruption, while sales back to Sweden are more positively affected by corruption when including these two variables. To conclude, our main results for corruption remain robust when including other measures of institutional quality. 
[Table 4 here]

We also do some further robustness checks that are not presented in the tables. The results are robust to the inclusion of other measures of institutional quality (law and order and bureaucracy quality) from the International Country Risk Guide (ICRG), as well as our measure of infrastructure quality (Electricity). Finally, we use the Transparency International Corruption Perception Index (TI) as a measure of corruption. A problem with the TI measure is that it is highly correlated with GDP per capita (-0.763). However, the asymmetric pattern in terms of the effect of corruption appears again, although the effects are not as strong.

\subsection{Effects of Corruption Over Time}

The cross-section analysis clearly indicates that corruption affects both the probability of a firm investing in a country and the level of investment. Since our major concern is that the results are driven by omitted variables, we further explore the question by studying the impact of changes in corruption. Our data from IFN provides a unique opportunity to study the impact over time. The panel analysis, however, also introduces some new concerns, the main one being that the measures of corruption vary little over the time periods they are available for. ${ }^{18}$

In addition to addressing the omitted variables issue, panel data enables analysis of whether Swedish multinational firms have potentially been impacted by a policy change 
during the late 1990s. ${ }^{19}$ In 1997, Sweden, together with other OECD and some non-OECD countries, signed a convention that made it a crime to bribe foreign government officials. As Kaufmann and Wei (1999) point out, this treaty may have strengthened the ability of OECD firms to reject bribery demands from corrupt officials, relative to firms from nonsigning countries, without necessarily losing business. We address this issue by estimating the effect of corruption separately for the period before and after 1997.

The IFN data has been collected roughly every four years since the 1970s. Here we make use of data on foreign investments of Swedish multinationals for 1986, 1990, 1994 and $1998 .^{20}$ We lack data for some control variables included in the cross-section analysis, but we are now able to include country, firm and time dummies to control for effects not captured by control variables. ${ }^{21}$

[Table 5 here]

In the first column we see that the negative effect of corruption on a firm's propensity to invest in a host country remains even when we control for country, firm and year specific effects. The next two columns present the results when controlling for Invest risk and Wage cost. Including investment risk has no effect on the results. The effect of corruption is no longer statistically significant when including Wage cost. However, this is due to the specific sample for which Wage cost are available. When restricting the sample to observations for which we have data on Wage cost, the effect of corruption is not statistically significant (see column four). 
In the last column, we analyze the effect of the OECD treaty allowing the effect of corruption to differ before and after 1997. We find no effects of the treaty on the investment behaviour of Swedish MNEs.

We have also run panel regressions for different types of affiliate sales. The results suggest that corruption has no effect on the size of the investment, except for the case of local sales, where corruption is found to have a positive effect, albeit significant at the ten percent level. This positive effect is no longer significant if observations for 1986 are excluded from the sample.

\subsection{Instrumental Variables}

Another concern may be that corruption is not measured properly, leading to measurement problems that in turn result in biased and inconsistent estimates. One way to remedy this problem is to use an instrumental variable approach. Another concern is possible reversed causality: foreign direct investments affect corruption. Although Swedish firms are unlikely to have any greater influence on corruption in a country, Swedish firms may act as other firms in the world economy. We can capture the causal effect by instrumenting for the effect of corruption with a factor that is not determined by the investment flows at the time.

A valid instrument should be correlated with corruption and not with other factors determining investment levels. Well-functioning instruments are not easy to find, since the causes of corruption are difficult to disentangle, and the factors affecting corruption prob- 
ably also influence the investment climate in other dimensions as well. We will here make use of factors that have been put forward in the literature that studies the determinants of corruption and institutions.

Teisman (2000) empirically tests different theories of the causes of corruption and finds, among other things, that countries with protestant traditions, more developed economies, and countries with a long exposure to democracy are less corrupt. He mentions two ways in which religion can affect corruption. First, Protestantism is regarded as less hierarchical than other major religions, and challenges to office-holders may therefore be more common in countries with a large protestant population. Another channel is the relationship between church and state. In most countries, Protestantism arose as a dissenting movement opposed to the state-sponsored religion, which may have induced the church to develop institutions that could monitor and denounce abuses by state officials. The risk of exposure is also likely to be higher in democratic countries because, for example, misuse of resources can be exposed in the media and voters can keep state officials accountable through elections. Based on Teisman (2000), we will use the share of the population professing protestant faith and the exposure to democracy as instruments for country level corruption. A potential problem with these instruments is that they may pick up the effect that firms prefer to invest in countries similar to their home country. In our case the home country (Sweden) is protestant and has been exposed to democracy for a long time.

Acemoglu et al (2001) proposes European settler mortality as an instrument for the functioning of a country's institutions. Their hypothesis is that Europeans adopted different colonial strategies depending on the mortality rates faced by the settlers. In countries 
where mortality rates were high, the settlers set up extractive institutions, which persist until today. We will here use the Acemoglu et al (2001) measure of settler mortality as an instrument for corruption. As this variable only exists for colonized countries, the sample of countries will be much smaller.

The first column in Table 6 shows the result from a probit estimation using the share of population professing protestant faith, and exposure to democracy, as instruments for the level of corruption. The first column in Table 7 shows the result using log of European settler mortality from Acemoglu et al (2001). The results indicate that there is indeed a negative effect of corruption on the probability that a firm will invest. The effect is strong and the point estimates are larger than in the probit estimation in Table $2 .{ }^{22}$ Larger estimates may indicate that there are measurement problems with corruption, which bias the estimates toward zero. The Wald test of exogeneity of the instrumental variables shows that there is not sufficient information to confirm an endogeneity problem in the sample in Table 6. In Table 7, however, the Wald test shows that there is an endogeneity problem and that the instrumental variable approach is the appropriate method. Noticeable is that the corporate tax rate has the predicted negative influence on investments in the sample of countries for which the mortality variable is available.

[Table 6 and Table 7 ]

In the next four columns of Tables 6 and 7 , we use the same instruments for corruption in the estimations for the different types of affiliate sales. The instruments perform well 
according to the exogeneity test, and the F-tests indicate that the instruments are correlated with corruption. According to the result in Table 6, corruption has a positive effect on sales back to the home country and no impact on the other types of flow. Table 7 shows the results when using settler mortality rates to instrument for corruption. ${ }^{23}$ Interestingly, the results here support our earlier conclusions in Section 4.2 that corruption reduces local sales but has no effect on sales back to home country. In this limited sample, the OLS estimates for corruption show a larger negative effect on local sales, and a statistically significant negative effect on total sales, which was not the case in the larger sample of countries used in Table 2.

To conclude, we find support for the previous results that corruption has a negative impact on the probability of a firm investing in a country. Furthermore, corruption is found to have a significant negative effect on local sales (horizontal FDI) when using log mortality rate as an instrument, while it has a positive effect on affiliate sales back to home country (vertical FDI) when using the share of population professing the protestant faith and the exposure to democracy as instruments.

\subsection{Corruption, FDI and Firm Characteristics}

So far, we have assumed the effect of corruption to be the same for all firms. However, firms facing the same policies and institutions in a country may end up paying different amount of bribes for the same services. If bribes are determined in a bargaining framework, the effect of corruption depends on the firm's bargaining power. This is suggested by 
Svensson (2003), who shows that public officials demand fewer bribes from firms with greater bargaining strength. Examples of firm-specific factors that may affect a firm's bargaining strength are size and R\&D-intensity. Large firms may make larger investments, giving them a stronger position, and R\&D-intensive investments may be attractive to the foreign country, thereby raising the firm's resistance to pay bribes to local officials.

Table 8 shows the results when we interact firm size and R\&D-intensity with corruption when studying total investments. As is evident from the two first columns, size does not seem to affect the impact of corruption on the firm's probability to invest. However, the last column shows that R\&D-intensive firms are less, or in fact not at all, affected by corruption when deciding where to invest. This could be because R\&D-intensive firms have stronger bargaining power and are thus less affected by corruption.

[Table 8 here]

\section{Conclusions}

Different motives lie behind foreign direct investments (FDI). In a simple model of the multinational firm, we study the impact of corruption on vertical investment (for sales back to the home country) and horizontal investments (for sales to the local market). Our model shows that the impact of corruption may be asymmetric in two different dimensions: (i) corruption may affect the probability that a firm chooses to invest, but not the size of affiliate activities once the firm has decided to invest, and (ii) corruption may have a 
differential effect depending on the type of investment, as measured by different types of affiliate activities.

We study the impact of corruption on the different investment flows identified in the model using data on Swedish multinational firms. We find that firms are less likely to invest in corrupt countries, and that horizontal investments aimed at local sales are to a larger extent hampered by corruption, whereas no robust effects are found on vertical and export platform investments, measured as sales back to Sweden and sales to third countries respectively. The explanation, in line with our model, is that producing and selling in a country, as opposed to exporting the production to other markets, incur larger costs to the firm because of greater involvement in the country. An alternative explanation to a less detrimental effect of corruption on vertical investments may be found in the new literature on the organization of the multinational firm (Helpman, 2006). According to these models, a firm may choose intra-firm trade, as opposed to arms-length trade, with countries characterized by a poor contracting environment. Since we expect the contracting environment to be poor in countries where corruption is prevalent, we expect firms to keep a larger share of trade with a corrupt country within the firm.

We also find that larger firms are less adversely affected by corruption. Certain firm characteristics can therefore improve the ability to reject bribery demands, as suggested by Svensson (2003).

Even though we have very detailed data on firms' investment decisions, we lack firmlevel data on the cost of corruption for different types of investment. To understand 
the exact mechanism through which corruption impacts firm behavior, further empirical research on the effects of corruption on firms' costs and behavior are important. Svensson (2003) and Fisman and Svensson (2000) are among the contributors in this area.

\section{Notes}

${ }^{1}$ One can extend the model into a framework where a corrupt official and a MNE bargain over the size of the bribe (and possibly also over the effect of the bribe). Such an extension will not qualitatively affect the theoretical predictions of the model, since the bribe would be determined by the parties' bargaining power, which in turn will depend on some exogenous factor related to the institutional setting.

${ }^{2}$ In the empirical analysis, we use outward investments for Swedish MNEs. Since Sweden is ranked as one of the least corrupt countries (Transparency International, 2003), this assumption is consistent with the data we will use.

${ }^{3}$ We could instead assume that the MNE refuses to pay bribes and is therefore punished by the corrupt official, which in turn increases the production costs of the MNE.

${ }^{4}$ The model can be extended to allow for direct exports.

${ }^{5}$ An example of such constraints are the US Foreign Corrupt Practices Act of 1977 and the OECD convention from 1997, crimilizing bribes paid by firms in foreign countries. The impact of the latter is studied more closely in Section 4.3. 
${ }^{6}$ All reporting foreign affiliates have own production, while affiliates functioning as sales officies are not included in the survey. In 1998, 97 out of 119 multinational firms reported the information required in this study for operations at the affiliate level.

${ }^{7}$ The total affiliate sales variable is defined as affiliate production, which excludes affiliate sales of imported goods.

${ }^{8}$ See, for example, Ekholm et al (2003) and Yeaple (2003).

${ }^{9}$ The division of affiliate sales for U.S. MNEs is similar with local sales accounting for 56 percent of total sales, exports back to the U.S. account for 16 percent, while 28 percent are exports to other countries in 1998 (Braconier et al, 2005).

${ }^{10} \mathrm{ICRG}$ is re-calculated as Corruption $=(6-\mathrm{ICRG}) / 6$, where 6 is the maximum value of the ICRG index.

${ }^{11}$ Because of confidentiality reasons, we only present variables describing firm production when there are more than three firms in the country.

${ }^{12}$ For a thorough discussion of the determinants of FDI, and the proxies used in the literature, see Barba Naveretti and Venables (2004).

${ }^{13}$ Country $i$ 's market potential is measured as $M P_{i}=\sum x_{j} / d_{i j}$, where $x_{j}$ is the GDP of country $j$ and $d_{i j}$ a measure of the geographical distance between countries $i$ and $j$. We have measured $d_{i j}$ as the greater circle distance between capitals when $j \neq i$. The data is from Penn World Tables 6. 
${ }^{14}$ We also compute trade barrier variables for non-tariff barriers $(N T B)$. The aggregation of NTBs is, however, rather ad hoc since NTB is a dummy variable solely indicating whether a certain type of NTB exists, without giving an indication of how extensive is its use. Regression results for NTBs are therefore not reported.

${ }^{15}$ To compute the tariffs, we use a data set put together by Haveman. It includes annual tariff, non-tariff barriers and trade data at the six-digit HS industry level for 103 countries. All tariff variables are computed as unweighted or weighted averages at the level of a fourdigit industry where the largest share of the affiliate production takes place. For a number of affiliates, the industry codes are available only at the two- or three-digit levels. We only report results for the unweighted mean tariffs.

${ }^{16}$ This was also illustrated by the equation $(2.2)$ in the model of Section 2 , where the investment decision is influenced by several types of affiliate activities.

${ }^{17}$ From (3.2), we can derive $\frac{\Delta q_{i j}}{q_{i j}}=e^{\alpha \Delta \text { Corruption }}-1$, where $\Delta q_{i j}$ is the associated change in affiliate sales and $\Delta$ Corruption is the the change in corruption. Inserting the regression coefficient $\alpha$ from the different specifications of (3.2) and noting that a change of one grade in our rescaled index is equal to 0.17 provides these estimates.

${ }^{18}$ The standard deviation of our corruption measure icrg is in 19981.28 wheras the within variation in the panel data is 0.64 . We do not use the Transparency International measure as year-to-year comparisons of a country's score do not only result from a changing perception of a country's performance, but also from a changing sample and methodology. Therefore, comparisons with the views collected in previous years can be misleading. For 
more information, see http://www.transparency.org.

${ }^{19}$ We thank the referee for this suggestion.

${ }^{20} \mathrm{IFN}$ has also collected data for 2003. We choose not to include this year in our study for several reasons. The response rate was only 30 percent which can be compared to more than 80 percent in the previous surveys. In addition, the sample is no longer representative because the loss of observations is concentrated among small and mediumsized firms. Moreover, the quality of the data in the 2003 survey is not as good as in previous years. For instance, there is less detailed information on affiliate trade.

${ }^{21}$ Our industry dummy variables are defined as five broader categories according a taxonomy in OECD (1987, 1992): resource intensive, labor intensive, scale intensive, differentiated goods and science based goods. Panel data is lacking for tax, labor, scale and tariffs and EPZ. Distance does not vary over time.

${ }^{22}$ Note that the larger estimates are not due to the restricted sample. The effect of corruption is larger in the sample in Table 7 (-2.403), but the instrumental analysis yields much larger estimates.

${ }^{23}$ Since there are very few observations, we hade to remove some of the explanatory variables used in the basic specifications. Exchanging some of the included explanatory variables with some of the excluded explanatory variables does not change the result. 


\section{References}

[1] Acemoglu, Daron, Simon Johnson, and James A. Robinson, "The Colonial Origins of Comparative Development: An Empirical Investigation," American Economic Review 91:5 (2001), 1369-1401.

[2] Alvarez, Mike, José Antonio Cheibub, Fernando Limongi, and Adam Przeworski, "Classifying Political Regimes," Studies in Comparative International Development $31: 2(1996), 3-36$.

[3] Barba Navaretti, Giorgio, and Anthony J. Venables, Multinational Firms in the World Economy (New Jersey: Princeton University Press, 2004).

[4] Barrett, David (Ed), World Christian Encyclopedia (New York: Oxford University Press, 1982).

[5] Barro, Robert J., and Jong-Wha Lee, "International Data on Educational Attainment: Updates and Implications," CID working paper no. 42 (2000), Harvard University.

[6] Braconier, Henrik, Pehr-Johan Norbäck, and Dieter Urban, "Multinational Enterprises and Wage Costs: Vertical FDI Revisited," Journal of International Economics 67:2 (2005), 446-70.

[7] Bardhan, Pranab, "Corruption and Development: A Review of Issues," Journal of Economic Literature 35:3 (1997), 1320-46. 
[8] Djankov, Simeon, Rafael La Porta, Florencio Lopez-De-Silanes, and Andrei Shleifer, "The Regulation of Entry," Quarterly Journal of Economics, 117:1 (2002), 1-37.

[9] Ekholm, Karolina, "Proximity Advantages, Scale Economies, and the Location of Production," in P. Braunerhjelm and K. Ekholm (Eds.), The Geography of Multinational Firms (Boston: Kluwer Academic, 1998).

[10] Ekholm, Karolina, Rikard Forslid, and James R. Markusen, "Export-Platform Foreign Direct Investment," Journal of European Economic Association 5:4 (2007), 776-795.

[11] Fisman, Raymond, and Jakob Svensson, "Are Corruption and Taxation Really Harmful to Growth? Firm-Level Evidence," Journal of Development Economics 83:1 (2007), 63-75.

[12] Hakkala, Katariina, Pehr-Johan Norbäck, and Helena Svaleryd, "Asymmetric Effects of Corruption on FDI: Evidence from Swedish Multinational Firms," IFN working paper 641 (2005), Stockholm: Research Institute of Industrial Economics.

[13] Harris, Chauncy D., "The Market Factor in the Localization of Industry in the United States," Annals of the Association of American Geographers 64 (1954), 315-348.

[14] Helpman, Elhanan., Marc J. Melitz, and Stephen R. Yeaple (2004), "Export versus FDI with Heterogeneous Firms," American Economic Review 94:1 (2004), 300-316.

[15] Helpman, Elhanan, "Trade, FDI, and the Organization of Firms," Journal of Economic Literature 44:3 (2006), 589-630. 
[16] Hines, James R., "Forbidden Payment: Foreign Bribery and American Business After 1977," NBER working paper no. 5266 (1995).

[17] Hines, James R., "Lessons from Behavioral responses to International Taxation," National Tax Journal 52:2 (1999), 305-322.

[18] Kaufmann Daniel, and Shang-Jin Wei, "Does Grease Money Speed up the Wheels of Commerce?," World Bank Research working paper no. 2254 (1999).

[19] La Porta, Rafael, Florencio Lopez-de-Silanes, Andrei Shleifer, and Robert W. Vishny, "The Quality of Government," Journal of Law, Economics and Organization 15:11 (1999), 222-279.

[20] Lui, Francis T., "An Equilibrium Queuing Model of Bribery," Journal of Political Economy 93:4 (1985), 760-81.

[21] Mutti, John, and Harry Grubert, "Empirical Asymmetries in Foreign Direct Investment and Taxation," Journal of International Economics 62:2 (2004), 337-358.

[22] Norbäck, Pehr-Johan, "Multinational Firms, Technology and Location," Journal of International Economics 54:2 (2001), 449-469.

[23] OECD, Structural Adjustment and Economic Performance (Paris: Organization for Economic Co-operation and Development, 1987).

[24] OECD, Industrial Policy in OECD Countries, (Paris: Organization for Economic Co-operation and Development, 1992). 
[25] Shleifer, Andrei, and Robert W. Vishny, "Corruption," Quarterly Journal of Economics 108:3 (1993), 599-617.

[26] Smarzynska, Beata K., and Shang-Jin Wei, "Corruption and Composition of Foreign Direct Investment: Firm-level Evidence," NBER working paper no. 7969 (2000).

[27] Svensson, Jakob, "Who Must Pay Bribes and How Much? Evidence from a Cross Section of Firms," Quarterly Journal of Economics 118:1 (2003), 207-30.

[28] Treisman, Daniel, "The Causes of Corruption: A Cross National Study," Journal of Public Economics 76:3 (2000), 399-457.

[29] Transparency International, Global Corruption Report (Cambridge: Cambridge University Press, 2003).

[30] Yeaple, Stephen.R., "The Complex Integration Strategies of Multinationals and Cross Country Dependencies in the Structure of Foreign Direct Investment," Journal of International Economics 60:2 (2003), 293-314.

[31] Wei, Shang-Jin, "Why is Corruption So Much More Taxing Than Tax? Arbitrariness Kills," NBER working paper no. 6255 (1997).

[32] Wei, Shang-Jin, "How Taxing Is Corruption on International Investors?," The Review of Economics and Statistics 82:1 (2000), 1-11. 
Table 1. The sample of countries 1998

\begin{tabular}{|c|c|c|c|c|c|c|c|c|c|}
\hline Country & Corruption & $\begin{array}{l}\text { No. of } \\
\text { firms }\end{array}$ & $\begin{array}{c}\text { Total } \\
\text { production }\end{array}$ & $\begin{array}{c}\text { Average share of } \\
\text { production } \\
\text { sold on local market }\end{array}$ & Country & Corruption & $\begin{array}{l}\text { No. of } \\
\text { firms }\end{array}$ & $\begin{array}{c}\text { Total } \\
\text { production }\end{array}$ & $\begin{array}{c}\text { Average share of } \\
\text { production } \\
\text { sold on local market }\end{array}$ \\
\hline Germany & 0.167 & 28 & 4332.960 & 0.443 & Argentina & 0.667 & $1-3$ & $*$ & $*$ \\
\hline Great Britain & 0.167 & 26 & 1406.785 & 0.612 & Kenya & 0.667 & $1-3$ & $*$ & * \\
\hline USA & 0.333 & 26 & 9694.806 & 0.702 & Thailand & 0.667 & $1-3$ & * & * \\
\hline Denmark & 0.000 & 25 & 765.010 & 0.445 & Turkey & 0.667 & $1-3$ & * & * \\
\hline Poland & 0.167 & 21 & 439.331 & 0.431 & Colombia & 0.750 & $1-3$ & $*$ & $*$ \\
\hline France & 0.333 & 20 & 1412.930 & 0.553 & Indonesia & 0.792 & $1-3$ & $*$ & $*$ \\
\hline Finland & 0.000 & 18 & 577.683 & 0.576 & Costa Rica & 0.167 & 0 & . & . \\
\hline Netherlands & 0.000 & 16 & 709.960 & 0.474 & New Zeeland & 0.167 & 0 & . & . \\
\hline Spain & 0.167 & 15 & 1562.754 & 0.512 & Chile & 0.333 & 0 & . & . \\
\hline Italy & 0.389 & 15 & 3178.432 & 0.444 & Congo & 0.333 & 0 & . & . \\
\hline Norway & 0.167 & 14 & 206.114 & 0.572 & Dominican Rep. & 0.333 & 0 & . & . \\
\hline Belgium & 0.500 & 14 & 4650.570 & 0.139 & El Salvador & 0.333 & 0 & . & . \\
\hline Brazil & 0.500 & 12 & 2021.274 & 0.713 & Guatemala & 0.333 & 0 & . & . \\
\hline Canada & 0.000 & 8 & 1918.832 & 0.279 & Iran & 0.333 & 0 & . & . \\
\hline Austria & 0.333 & 8 & 288.897 & 0.484 & Malta & 0.333 & 0 & . & . \\
\hline China & 0.667 & 8 & 129.566 & 0.489 & Mozambique & 0.333 & 0 & . & . \\
\hline India & 0.500 & 7 & 123.780 & 0.668 & Nicaragua & 0.333 & 0 & . & . \\
\hline Mexico & 0.500 & 6 & 111.917 & 0.655 & Papau. New Guinuea & 0.333 & 0 & . & . \\
\hline Switzerland & 0.167 & 4 & 152.354 & 0.499 & Bahrain & 0.500 & 0 & . & . \\
\hline Australia & 0.167 & 4 & 121.813 & 0.447 & Bolivia & 0.500 & 0 & . & . \\
\hline Hungary & 0.167 & 4 & 207.731 & 0.433 & Ecuador & 0.500 & 0 & . & . \\
\hline Malaysia & 0.375 & 4 & 20.579 & 0.333 & Jamaica & 0.500 & 0 & . & . \\
\hline Japan & 0.639 & 4 & 119.285 & 0.589 & Malawi & 0.500 & 0 & . & . \\
\hline Greece & 0.167 & $1-3$ & $*$ & $*$ & Trinidad \& Tobago & 0.500 & 0 & . & . \\
\hline Portugal & 0.167 & $1-3$ & * & * & Uruguay & 0.500 & 0 & . & . \\
\hline Korea & 0.333 & $1-3$ & $*$ & $*$ & Venezuela & 0.500 & 0 & . & . \\
\hline Singapore & 0.333 & $1-3$ & * & * & Cameroon & 0.667 & 0 & . & . \\
\hline South Africa & 0.389 & $1-3$ & * & $*$ & Egypt & 0.667 & 0 & . & . \\
\hline Philippines & 0.431 & $1-3$ & * & * & Honduras & 0.667 & 0 & . & . \\
\hline Ireland & 0.500 & $1-3$ & $*$ & $*$ & Panama & 0.667 & 0 & . & . \\
\hline Peru & 0.500 & $1-3$ & $*$ & * & Paraguay & 0.667 & 0 & . & . \\
\hline Zambia & 0.500 & $1-3$ & $*$ & $*$ & Uganda & 0.667 & 0 & . & . \\
\hline Zimbabwe & 0.667 & $1-3$ & $*$ & $*$ & & & & & \\
\hline
\end{tabular}

* When the number of firms is lower than 4 we are not able to display any more information because of confidentiality reasons. 
Table 2. Basic specifications

\begin{tabular}{|c|c|c|c|c|c|}
\hline $\begin{array}{l}\text { Dependent } \\
\text { variable }\end{array}$ & Total sales & Total sales & Local sales & $\begin{array}{c}\text { Sales to home } \\
\text { country }\end{array}$ & $\begin{array}{c}\text { Sales to } 3^{\text {rd }} \\
\text { countries }\end{array}$ \\
\hline & Probit & OLS & OLS & OLS & OLS \\
\hline Corruption & $\begin{array}{c}-0.925^{* * *} \\
(2.71)\end{array}$ & $\begin{array}{l}-0.291 \\
(0.33)\end{array}$ & $\begin{array}{c}-1.261^{*} \\
(1.85)\end{array}$ & $\begin{array}{c}2.191 * * * \\
(3.07)\end{array}$ & $\begin{array}{l}1.720^{*} \\
(1.74)\end{array}$ \\
\hline GDP/capita & $\begin{array}{r}-0.155 \\
(1.35)\end{array}$ & $\begin{array}{c}0.703^{* *} \\
(2.23)\end{array}$ & $\begin{array}{l}0.501 \\
(1.68)\end{array}$ & $\begin{array}{r}-0.158 \\
(0.30)\end{array}$ & $\begin{array}{c}0.889 * * * \\
(3.47)\end{array}$ \\
\hline GDP & $\begin{array}{c}0.456 * * * \\
(11.25)\end{array}$ & $\begin{array}{c}0.348 * * * \\
(3.80)\end{array}$ & $\begin{array}{c}0.649 * * * \\
(6.69)\end{array}$ & $\begin{array}{l}0.127 \\
(0.81)\end{array}$ & $\begin{array}{c}0.251^{*} \\
(1.90)\end{array}$ \\
\hline Market pot. & $\begin{array}{l}-0.058 \\
(0.48)\end{array}$ & $\begin{array}{l}0.061 \\
(0.32)\end{array}$ & & & $\begin{array}{c}1.238 * * * \\
(5.26)\end{array}$ \\
\hline Tax & $\begin{array}{l}0.419^{*} \\
(1.90)\end{array}$ & $\begin{array}{l}0.547 \\
(0.94)\end{array}$ & $\begin{array}{l}0.418 \\
(0.88)\end{array}$ & $\begin{array}{l}0.393 \\
(0.43)\end{array}$ & $\begin{array}{r}-0.432 \\
(0.67)\end{array}$ \\
\hline Distance & $\begin{array}{c}-0.564 * * * \\
(5.61)\end{array}$ & $\begin{array}{l}-0.348^{*} \\
(1.75)\end{array}$ & $\begin{array}{l}-0.269 \\
(1.19)\end{array}$ & $\begin{array}{c}-0.794 * * \\
(2.17)\end{array}$ & $\begin{array}{l}-0.352 \\
(1.33)\end{array}$ \\
\hline Labor & $\begin{array}{l}-0.047 \\
(0.25)\end{array}$ & $\begin{array}{l}0.108 \\
(0.21)\end{array}$ & $\begin{array}{l}0.258 \\
(0.54)\end{array}$ & $\begin{array}{c}1.261 * * \\
(2.43)\end{array}$ & $\begin{array}{l}-0.431 \\
(0.64)\end{array}$ \\
\hline Size & $\begin{array}{c}0.394 * * * \\
(13.40)\end{array}$ & $\begin{array}{c}0.525 * * * \\
(8.17)\end{array}$ & $\begin{array}{c}0.536 * * * \\
(8.35)\end{array}$ & $\begin{array}{c}0.386 * * * \\
(6.58)\end{array}$ & $\begin{array}{c}0.562 * * * \\
(6.67)\end{array}$ \\
\hline $\mathrm{R} \& \mathrm{D}$ & $\begin{array}{c}-3.902 * * * \\
(3.96)\end{array}$ & $\begin{array}{c}-1.064 \\
(0.63)\end{array}$ & $\begin{array}{c}-7.312 * * * \\
(2.73)\end{array}$ & $\begin{array}{l}3.703 \\
(1.12)\end{array}$ & $\begin{array}{l}2.902 \\
(0.61)\end{array}$ \\
\hline Scale hor & $\begin{array}{c}-0.167 * * * \\
(4.84)\end{array}$ & $\begin{array}{c}0.226 * * * \\
(4.30)\end{array}$ & $\begin{array}{c}0.241 * * * \\
(3.98)\end{array}$ & & $\begin{array}{c}0.319 * * * \\
(3.66)\end{array}$ \\
\hline Scale ver & & & & $\begin{array}{l}-0.024 \\
(0.23)\end{array}$ & \\
\hline Tariff_hor & $\begin{array}{l}-0.003 \\
(0.10)\end{array}$ & $\begin{array}{l}0.077 \\
(0.79)\end{array}$ & $\begin{array}{c}0.174 * * \\
(2.16)\end{array}$ & & \\
\hline Tariff_ver & $\begin{array}{c}-0.109^{* * *} \\
(2.77)\end{array}$ & $\begin{array}{l}-0.084 \\
(0.73)\end{array}$ & & $\begin{array}{l}0.008 \\
(0.09)\end{array}$ & \\
\hline Tariff_plat & $\begin{array}{c}-0.094 \\
(0.44)\end{array}$ & & & & $\begin{array}{l}-0.171 \\
(0.43)\end{array}$ \\
\hline EPZ & $\begin{array}{c}-0.347 * * * \\
(3.44)\end{array}$ & $\begin{array}{c}0.330^{*} \\
(1.70)\end{array}$ & $\begin{array}{l}0.046 \\
(0.26)\end{array}$ & $\begin{array}{l}0.286 \\
(1.06)\end{array}$ & $\begin{array}{c}0.984 * * * \\
(3.76)\end{array}$ \\
\hline Constant & $\begin{array}{c}-8.951^{* * *} \\
(4.10)\end{array}$ & $\begin{array}{c}-16.178^{* * * *} \\
(3.55)\end{array}$ & $\begin{array}{c}-24.421^{* * * *} \\
(6.54)\end{array}$ & $\begin{array}{l}-5.704 \\
(1.01)\end{array}$ & $\begin{array}{c}-25.901 * * * \\
(4.60)\end{array}$ \\
\hline Trade area effects & yes & yes & yes & yes & yes \\
\hline Observations & 6060 & 297 & 271 & 184 & 237 \\
\hline Pseudo R2/ R2 & 0.42 & 0.60 & 0.62 & 0.29 & 0.53 \\
\hline
\end{tabular}


Table 3. Heckman estimations

\begin{tabular}{|c|c|c|c|c|c|c|c|c|}
\hline \multirow[t]{2}{*}{$\begin{array}{l}\text { Dependent } \\
\text { variable }\end{array}$} & \multicolumn{2}{|c|}{ Total sales } & \multicolumn{2}{|c|}{ Local sales } & \multicolumn{2}{|c|}{$\begin{array}{c}\text { Sales back to home } \\
\text { country }\end{array}$} & \multicolumn{2}{|c|}{ Sales to $3^{\text {rd }}$ country } \\
\hline & Level & select & level & select & level & select & level & select \\
\hline Corruption & $\begin{array}{c}-0.617 \\
(0.66)\end{array}$ & $\begin{array}{c}-0.846 * * \\
(2.48)\end{array}$ & $\begin{array}{c}-1.585 * * \\
(2.41)\end{array}$ & $\begin{array}{c}-0.782 * * \\
(2.52)\end{array}$ & $\begin{array}{l}1.127 \\
(0.97)\end{array}$ & $\begin{array}{c}-0.626 \\
(1.38)\end{array}$ & $\begin{array}{c}1.627 * \\
(1.75)\end{array}$ & $\begin{array}{c}-0.741 * \\
(1.96)\end{array}$ \\
\hline GDP/capita & $\begin{array}{c}0.643 * * \\
(2.01)\end{array}$ & $\begin{array}{c}-0.112 \\
(0.96)\end{array}$ & $\begin{array}{l}0.412 \\
(1.38)\end{array}$ & $\begin{array}{r}-0.092 \\
(0.78)\end{array}$ & $\begin{array}{l}-0.129 \\
(0.21)\end{array}$ & $\begin{array}{l}0.175 \\
(1.00)\end{array}$ & $\begin{array}{c}1.087 * * * \\
(2.69)\end{array}$ & $\begin{array}{l}0.063 \\
(0.44)\end{array}$ \\
\hline GDP & $\begin{array}{l}0.529 * * * \\
(4.86)\end{array}$ & $\begin{array}{c}0.435 * * * \\
(11.75)\end{array}$ & $\begin{array}{l}0.817 * * * \\
(6.84)\end{array}$ & $\begin{array}{c}0.409 * * * \\
(12.10)\end{array}$ & $\begin{array}{l}0.713 * * * \\
(3.40)\end{array}$ & $\begin{array}{l}0.353 * * * \\
(7.81)\end{array}$ & $\begin{array}{l}0.344 * * * \\
\quad(2.74)\end{array}$ & $\begin{array}{l}0.413 * * * \\
(8.81)\end{array}$ \\
\hline Market pot. & $\begin{array}{l}0.128 \\
(0.63)\end{array}$ & $\begin{array}{r}-0.015 \\
(0.13)\end{array}$ & & $\begin{array}{r}-0.050 \\
(0.50)\end{array}$ & & $\begin{array}{r}-0.031 \\
(0.25)\end{array}$ & $\begin{array}{l}1.111 * * * \\
(4.37)\end{array}$ & $\begin{array}{l}0.044 \\
(0.43)\end{array}$ \\
\hline Tax & $\begin{array}{l}0.772 \\
(1.29)\end{array}$ & $\begin{array}{c}0.453 * * \\
(2.12)\end{array}$ & $\begin{array}{l}0.654 \\
(1.43)\end{array}$ & $\begin{array}{c}0.346^{*} \\
(1.68)\end{array}$ & $\begin{array}{l}0.943 \\
(0.87)\end{array}$ & $\begin{array}{l}0.591 * * * \\
(2.59)\end{array}$ & $\begin{array}{l}-0.215 \\
(0.38)\end{array}$ & $\begin{array}{c}0.365^{*} \\
(1.77)\end{array}$ \\
\hline Distance & $\begin{array}{c}-0.532 * * \\
(2.54)\end{array}$ & $\begin{array}{c}-0.567 * * * \\
(5.74)\end{array}$ & $\begin{array}{c}-0.451 * \\
(1.83)\end{array}$ & $\begin{array}{l}-0.548 * * * \\
\quad(5.78)\end{array}$ & $\begin{array}{c}-1.689 * * * \\
(3.41)\end{array}$ & $\begin{array}{l}-0.775^{* * *} \\
\quad(8.14)\end{array}$ & $\begin{array}{l}-0.485 \\
(1.59)\end{array}$ & $\begin{array}{l}-0.452 * * * \\
\quad(4.90)\end{array}$ \\
\hline Labor & $\begin{array}{l}0.079 \\
(0.16)\end{array}$ & $\begin{array}{r}-0.152 \\
(0.79)\end{array}$ & $\begin{array}{l}0.178 \\
(0.39)\end{array}$ & $\begin{array}{r}-0.193 \\
(1.07)\end{array}$ & $\begin{array}{c}1.712^{* *} \\
(2.51)\end{array}$ & $\begin{array}{l}-0.119 \\
(0.52)\end{array}$ & $\begin{array}{r}-0.510 \\
(0.81)\end{array}$ & $\begin{array}{r}-0.119 \\
(0.66)\end{array}$ \\
\hline Size & $\begin{array}{c}0.653 * * * \\
(8.96)\end{array}$ & $\begin{array}{c}0.340 * * * \\
(13.38)\end{array}$ & $\begin{array}{c}0.661 * * * \\
(7.82)\end{array}$ & $\begin{array}{c}0.339 * * * \\
(12.65)\end{array}$ & $\begin{array}{c}0.835 * * * \\
(7.63)\end{array}$ & $\begin{array}{c}0.313 * * * \\
(12.13)\end{array}$ & $\begin{array}{c}0.677 * * * \\
(9.16)\end{array}$ & $\begin{array}{c}0.376^{* * * *} \\
(15.12)\end{array}$ \\
\hline R\&D & $\begin{array}{l}-2.268 \\
(1.40)\end{array}$ & $\begin{array}{c}-3.304 * * * \\
(3.56)\end{array}$ & $\begin{array}{c}-8.636^{* * *} \\
(3.52)\end{array}$ & $\begin{array}{c}-4.556 * * * \\
(4.07)\end{array}$ & $\begin{array}{l}1.019 \\
(0.40)\end{array}$ & $\begin{array}{c}-2.100 * * \\
(2.31)\end{array}$ & $\begin{array}{c}1.244 \\
(0.26)\end{array}$ & $\begin{array}{c}-3.340 * * * \\
(3.46)\end{array}$ \\
\hline Scale hor & $\begin{array}{c}0.174 * * * \\
(3.48)\end{array}$ & $\begin{array}{c}-0.140 * * * \\
(4.51)\end{array}$ & $\begin{array}{c}0.196^{* * * *} \\
(3.13)\end{array}$ & $\begin{array}{c}-0.134 * * * \\
(4.31)\end{array}$ & & $\begin{array}{c}-0.175^{* * *} * \\
(5.85)\end{array}$ & $\begin{array}{c}0.287 * * * \\
(3.62)\end{array}$ & $\begin{array}{c}-0.150 * * * \\
(4.26)\end{array}$ \\
\hline Scale ver & & & & & $\begin{array}{c}-0.240 * * \\
(2.30)\end{array}$ & & & \\
\hline Tariff_hor & $\begin{array}{l}0.075 \\
(0.77)\end{array}$ & $\begin{array}{l}0.004 \\
(0.13)\end{array}$ & $\begin{array}{c}0.149 * \\
(1.82)\end{array}$ & $\begin{array}{l}0.002 \\
(0.09)\end{array}$ & & $\begin{array}{c}0.088 * * * \\
(2.68)\end{array}$ & $\begin{array}{l}0.057 \\
(0.37)\end{array}$ & $\begin{array}{l}0.021 \\
(0.63)\end{array}$ \\
\hline Tariff_ver & $\begin{array}{l}-0.114 \\
(0.89)\end{array}$ & $\begin{array}{c}-0.106^{* * * *} \\
(3.24)\end{array}$ & & $\begin{array}{c}-0.100 * * * \\
(3.25)\end{array}$ & $\begin{array}{l}-0.108 \\
(0.69)\end{array}$ & $\begin{array}{c}-0.100 * * \\
(2.57)\end{array}$ & $\begin{array}{c}-0.214^{* *} \\
(2.36)\end{array}$ & $\begin{array}{c}-0.113 * * * \\
(3.16)\end{array}$ \\
\hline Tariff_plat & & $\begin{array}{c}-0.070 \\
(0.36)\end{array}$ & & $\begin{array}{r}-0.131 \\
(0.73)\end{array}$ & & $\begin{array}{l}-0.265 \\
(1.56)\end{array}$ & $\begin{array}{r}-0.137 \\
(0.34)\end{array}$ & $\begin{array}{c}-0.174 \\
(0.86)\end{array}$ \\
\hline EPZ & $\begin{array}{l}0.227 \\
(1.16)\end{array}$ & $\begin{array}{c}-0.350 * * * \\
(3.60)\end{array}$ & $\begin{array}{r}-0.032 \\
(0.19)\end{array}$ & $\begin{array}{c}-0.334 * * * \\
(3.78)\end{array}$ & $\begin{array}{r}0.194 \\
(0.56)\end{array}$ & $\begin{array}{r}-0.135 \\
(1.26)\end{array}$ & $\begin{array}{c}0.811 * * * \\
(2.77)\end{array}$ & $\begin{array}{c}-0.301 * * \\
(2.56)\end{array}$ \\
\hline Constant & $\begin{array}{c}-21.437 * * * \\
(4.47)\end{array}$ & $\begin{array}{c}-8.797 * * * \\
(4.39)\end{array}$ & $\begin{array}{c}28.364 * * * \\
(7.85)\end{array}$ & $\begin{array}{c}-7.605 * * * \\
(4.18)\end{array}$ & $\begin{array}{c}-23.557 * * * \\
(3.04)\end{array}$ & $\begin{array}{c}-8.003 * * * \\
(4.28)\end{array}$ & $\begin{array}{c}-29.841 * * * \\
(5.03)\end{array}$ & $\begin{array}{c}11.341 * * * \\
(6.36)\end{array}$ \\
\hline $\begin{array}{l}\text { Trade area } \\
\text { effects }\end{array}$ & Yes & yes & yes & yes & yes & yes & yes & yes \\
\hline $\begin{array}{l}\text { Rho } \\
\text { Wald test } \\
\text { of indep eq. } \\
\text { Obs. }\end{array}$ & 293 & $\begin{array}{c}0.41 \\
6.62 \\
(0.010) \\
6060\end{array}$ & 267 & $\begin{array}{c}0.37 \\
5.18 \\
(0.023) \\
6060\end{array}$ & 182 & $\begin{array}{c}0.87 \\
28.88 \\
(0.000) \\
6060\end{array}$ & 237 & $\begin{array}{c}0.26 \\
4.57 \\
(0.033) \\
6060\end{array}$ \\
\hline
\end{tabular}

Note: The Wald test of independent equations tests the hypothesis that rho $=0$. Standard errors clustered on country, $t-$

statistics in parentheses, $* * *$ significant at one, ${ }^{* *}$ at five and $*$ at ten percent level. 
Table 4. Add investment risk, time and wage costs

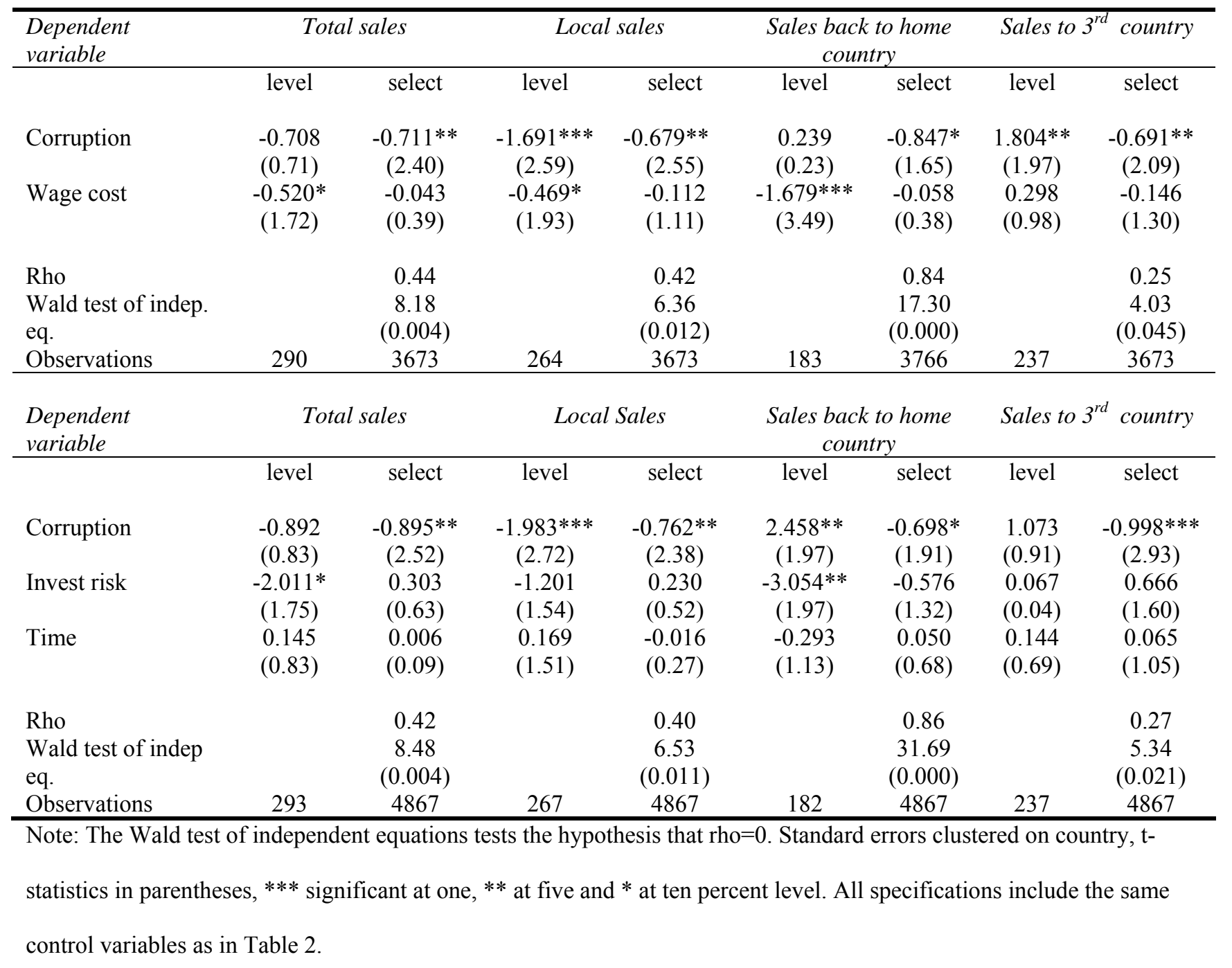


Table 5. Panel regressions 1986-1998

\begin{tabular}{|c|c|c|c|c|c|}
\hline Dependent variable & Total sales & Total sales & Total sales & Total sales & Total sales \\
\hline Corruption & $\begin{array}{c}-0.022 * * \\
(2.08)\end{array}$ & $\begin{array}{c}-0.020 * * \\
(2.00)\end{array}$ & $\begin{array}{l}-0.012 \\
(0.75)\end{array}$ & $\begin{array}{c}-0.016 \\
(1.00)\end{array}$ & $\begin{array}{c}-0.027 * * * \\
2.71)\end{array}$ \\
\hline Corruption*reform & & & & & $\begin{array}{l}0.023 \\
(1.33)\end{array}$ \\
\hline GDP/capita & $\begin{array}{l}-0.007 \\
(0.23)\end{array}$ & $\begin{array}{l}-0.005 \\
(0.14)\end{array}$ & $\begin{array}{l}0.046 \\
(0.78)\end{array}$ & $\begin{array}{c}0.040 \\
(0.68)\end{array}$ & $\begin{array}{l}0.010 \\
(0.33)\end{array}$ \\
\hline GDP & $\begin{array}{l}0.023 \\
(0.63)\end{array}$ & $\begin{array}{l}0.018 \\
(0.46)\end{array}$ & $\begin{array}{l}-0.005 \\
(0.09)\end{array}$ & $\begin{array}{l}-0.001 \\
(0.01)\end{array}$ & $\begin{array}{l}0.007 \\
(0.18)\end{array}$ \\
\hline Market pot. & $\begin{array}{l}0.044 \\
(0.46)\end{array}$ & $\begin{array}{l}0.063 \\
(0.69)\end{array}$ & $\begin{array}{c}0.271 * * \\
(2.36)\end{array}$ & $\begin{array}{c}0.275^{* *} \\
(2.26)\end{array}$ & $\begin{array}{l}0.024 \\
(0.25)\end{array}$ \\
\hline Size & $\begin{array}{c}0.035^{* * *} \\
(5.27)\end{array}$ & $\begin{array}{c}0.035 * * * \\
(5.27)\end{array}$ & $\begin{array}{c}0.050 * * * \\
(4.20)\end{array}$ & $\begin{array}{c}0.050 * * * \\
(4.20)\end{array}$ & $\begin{array}{c}0.035^{* * *} \\
(5.27)\end{array}$ \\
\hline$R \& D$ & $\begin{array}{r}-0.139 \\
(1.36)\end{array}$ & $\begin{array}{r}-0.139 \\
(1.36)\end{array}$ & $\begin{array}{r}-0.187 \\
(1.08)\end{array}$ & $\begin{array}{l}-0.187 \\
(1.08)\end{array}$ & $\begin{array}{c}0.139 * * * \\
(1.36)\end{array}$ \\
\hline Invest risk & & $\begin{array}{l}-0.012 \\
(0.83)\end{array}$ & & & \\
\hline Wage cost & & & $\begin{array}{l}0.000 \\
(1.01)\end{array}$ & & \\
\hline Country effects & Yes & Yes & Yes & Yes & Yes \\
\hline Firm effects & Yes & Yes & Yes & Yes & Yes \\
\hline Time effects & Yes & Yes & Yes & Yes & Yes \\
\hline Observations & 26293 & 26293 & 11824 & 11824 & 26293 \\
\hline R2 & 0.24 & 0.24 & 0.28 & 0.28 & 0.24 \\
\hline
\end{tabular}

Note: Dependent variable is a dummy that takes the value one if the firm has an investment in the country otherwise zero. The fourth column shows the results from regressions using the sample with observations where we have information on wage cost. All specifications are estimated using OLS, standard errors clustered on country and year, tstatistics in parentheses, $* * *$ significant at one, $* *$ at five and $*$ at ten percent level. 
Table 6. Instrumental variable estimations using democracy and protestant as instruments

\begin{tabular}{|c|c|c|c|c|c|}
\hline Dependent variable & Total Sales & Total sales & Local sales & $\begin{array}{l}\text { Sales back to } \\
\text { home country }\end{array}$ & $\begin{array}{l}\text { Sales to } 3^{\text {rd }} \\
\text { country }\end{array}$ \\
\hline & Probit & Level & Level & Level & Level \\
\hline Corruption & $\begin{array}{c}-1.359 * * \\
(1.98)\end{array}$ & $\begin{array}{l}2.253 \\
(1.50)\end{array}$ & $\begin{array}{l}-1.539 \\
(0.75)\end{array}$ & $\begin{array}{c}6.033^{* *} \\
(2.16)\end{array}$ & $\begin{array}{l}1.591 \\
(1.09)\end{array}$ \\
\hline GDP/capita & $\begin{array}{r}-0.243 \\
(1.49)\end{array}$ & $\begin{array}{c}1.144 * * * \\
(3.08)\end{array}$ & $\begin{array}{l}0.457 \\
(1.18)\end{array}$ & $\begin{array}{l}0.315 \\
(0.57)\end{array}$ & $\begin{array}{c}0.871 * * * \\
(3.57)\end{array}$ \\
\hline GDP & $\begin{array}{c}0.465 * * * \\
(10.22)\end{array}$ & $\begin{array}{c}0.228 * * \\
(2.00)\end{array}$ & $\begin{array}{c}0.662 * * * \\
(5.77)\end{array}$ & $\begin{array}{l}-0.056 \\
(0.33)\end{array}$ & $\begin{array}{c}0.258 * * \\
(2.03)\end{array}$ \\
\hline Market pot. & $\begin{array}{r}-0.046 \\
(0.33)\end{array}$ & $\begin{array}{l}0.076 \\
(0.32)\end{array}$ & & & $\begin{array}{c}1.236^{* * *} \\
(5.42)\end{array}$ \\
\hline Tax & $\begin{array}{c}0.447^{*} \\
(1.92)\end{array}$ & $\begin{array}{l}0.170 \\
(0.28)\end{array}$ & $\begin{array}{l}0.456 \\
(0.80)\end{array}$ & $\begin{array}{l}-0.578 \\
(0.64)\end{array}$ & $\begin{array}{l}-0.407 \\
(0.59)\end{array}$ \\
\hline Distance & $\begin{array}{c}-0.520 * * * \\
(4.22)\end{array}$ & $\begin{array}{c}-0.636 * * * \\
(2.65)\end{array}$ & $\begin{array}{l}-0.236 \\
(0.86)\end{array}$ & $\begin{array}{c}-1.149^{* *} \\
(2.20)\end{array}$ & $\begin{array}{l}-0.339 \\
(1.62)\end{array}$ \\
\hline Labor & $\begin{array}{r}-0.028 \\
(0.14)\end{array}$ & $\begin{array}{l}0.057 \\
(0.11)\end{array}$ & $\begin{array}{l}0.266 \\
(0.58)\end{array}$ & $\begin{array}{l}1.447^{*} \\
(1.81)\end{array}$ & $\begin{array}{r}-0.430 \\
(0.67)\end{array}$ \\
\hline Size & $\begin{array}{c}0.393 * * * \\
(13.38)\end{array}$ & $\begin{array}{c}0.529 * * * \\
(8.42)\end{array}$ & $\begin{array}{c}0.535 * * * \\
(8.86)\end{array}$ & $\begin{array}{c}0.387 * * * \\
(6.61)\end{array}$ & $\begin{array}{c}0.562 * * * \\
(7.07)\end{array}$ \\
\hline$R \& D$ & $\begin{array}{c}-3.878^{* * * *} \\
(4.00)\end{array}$ & $\begin{array}{r}-1.911 \\
(1.10)\end{array}$ & $\begin{array}{c}-7.170 * * * \\
(2.66)\end{array}$ & $\begin{array}{l}2.578 \\
(0.76)\end{array}$ & $\begin{array}{l}2.953 \\
(0.65)\end{array}$ \\
\hline Scale hor & $\begin{array}{c}-0.166^{* * * *} \\
(4.79)\end{array}$ & $\begin{array}{c}0.225^{* * *} \\
(4.40)\end{array}$ & $\begin{array}{c}0.241 * * * \\
(4.15)\end{array}$ & & $\begin{array}{c}0.319 * * * \\
(3.92)\end{array}$ \\
\hline Scale ver & & & & $\begin{array}{l}-0.038 \\
(0.39)\end{array}$ & \\
\hline Tariff_hor & $\begin{array}{c}-0.009 \\
(0.28)\end{array}$ & $\begin{array}{l}0.119 \\
(1.14)\end{array}$ & $\begin{array}{c}0.172^{* *} \\
(2.25)\end{array}$ & & \\
\hline Tariff_ver & $\begin{array}{c}-0.105^{* *} \\
(2.56)\end{array}$ & $\begin{array}{l}-0.144 \\
(1.41)\end{array}$ & & $\begin{array}{l}-0.093 \\
(0.75)\end{array}$ & \\
\hline Tariff_plat & $\begin{array}{r}-0.101 \\
(0.48)\end{array}$ & & & & $\begin{array}{l}-0.175 \\
(0.44)\end{array}$ \\
\hline EPZ & $\begin{array}{c}-0.356^{* * * *} \\
(3.41)\end{array}$ & $\begin{array}{c}0.487^{*} \\
(1.89)\end{array}$ & $\begin{array}{l}0.028 \\
(0.11)\end{array}$ & $\begin{array}{l}0.611 \\
(1.25)\end{array}$ & $\begin{array}{c}0.972 * * * \\
(3.61)\end{array}$ \\
\hline Constant & $\begin{array}{c}-8.792 * * * \\
(3.61)\end{array}$ & $\begin{array}{c}-14.384 * * * \\
(3.13)\end{array}$ & $\begin{array}{c}-24.669 * * * \\
(6.61)\end{array}$ & $\begin{array}{l}-1.223 \\
(0.17)\end{array}$ & $\begin{array}{c}-26.016^{* * *} \\
(5.29)\end{array}$ \\
\hline Trade area dummies & Yes & yes & yes & yes & yes \\
\hline Instruments & $\begin{array}{c}\text { Democracy, } \\
\text { protestant }\end{array}$ & $\begin{array}{c}\text { Democracy, } \\
\text { protestant }\end{array}$ & $\begin{array}{c}\text { Democracy, } \\
\text { protestant }\end{array}$ & $\begin{array}{c}\text { Democracy, } \\
\text { protestant }\end{array}$ & $\begin{array}{c}\text { Democracy, } \\
\text { protestant }\end{array}$ \\
\hline F-test excl. instruments & & $\begin{array}{l}41.90 \\
(0.000)\end{array}$ & $\begin{array}{l}10.40 \\
(0.000)\end{array}$ & $\begin{array}{c}28.34 \\
(0.000)\end{array}$ & $\begin{array}{c}32.18 \\
(0.000)\end{array}$ \\
\hline Wald test of exogenity & $\begin{array}{c}0.55 \\
(0.459)\end{array}$ & & & & \\
\hline OID test & & $\begin{array}{c}0.041 \\
(0.839)\end{array}$ & $\begin{array}{c}0.121 \\
(0.728)\end{array}$ & $\begin{array}{c}0.347 \\
(0.556)\end{array}$ & $\begin{array}{c}1.389 \\
(0.239)\end{array}$ \\
\hline Observations & 5594 & 297 & 271 & 184 & 237 \\
\hline
\end{tabular}


Standard errors clustered on country, t-statistics in parentheses, ${ }^{* *}$ significant at one, ${ }^{* *}$ at five and $*$ at ten percent level. 
Table 7. Instrumental variable estimations using mortality as instruments

\begin{tabular}{|c|c|c|c|c|c|}
\hline Dependent variable & Total sales & Total sales & Local sales & $\begin{array}{l}\text { Sales back to } \\
\text { home country }\end{array}$ & $\begin{array}{c}\text { Sales to } 3^{r a} \\
\text { countries }\end{array}$ \\
\hline & Probit & Level & Level & Level & Level \\
\hline Corruption & $\begin{array}{c}-7.555 * * * \\
(6.89)\end{array}$ & $\begin{array}{c}-9.619 * * * \\
(2.88)\end{array}$ & $\begin{array}{c}-9.531 * * \\
(2.05)\end{array}$ & $\begin{array}{l}-0.801 \\
(0.27)\end{array}$ & $\begin{array}{l}2.564 \\
(1.29)\end{array}$ \\
\hline GDP/capita & $\begin{array}{c}-1.542 * * * \\
(3.97)\end{array}$ & $\begin{array}{c}-2.110 * * * \\
(2.59)\end{array}$ & $\begin{array}{c}-2.332 * \\
(1.89)\end{array}$ & $\begin{array}{l}0.475 \\
(1.07)\end{array}$ & $\begin{array}{c}1.645^{* * * *} \\
(4.95)\end{array}$ \\
\hline GDP & $\begin{array}{c}0.499 * * \\
(2.31)\end{array}$ & $\begin{array}{c}1.461 * * * \\
(5.05)\end{array}$ & $\begin{array}{c}1.842 * * * \\
(4.28)\end{array}$ & & \\
\hline Market pot. & $\begin{array}{l}-0.427 \\
(0.67)\end{array}$ & $\begin{array}{l}-0.256 \\
(0.38)\end{array}$ & & & $\begin{array}{l}0.632 \\
(0.86)\end{array}$ \\
\hline Tax & $\begin{array}{l}-1.236 \\
(1.64)\end{array}$ & $\begin{array}{c}-2.522 * * * \\
(3.44)\end{array}$ & $\begin{array}{c}-1.378^{*} \\
(1.65)\end{array}$ & & $\begin{array}{c}-3.861 * * * \\
(2.59)\end{array}$ \\
\hline Distance & $\begin{array}{l}-0.354 \\
(0.74)\end{array}$ & $\begin{array}{c}0.348 \\
(0.25)\end{array}$ & $\begin{array}{l}2.074 \\
(1.25)\end{array}$ & $\begin{array}{l}1.131 \\
(0.94)\end{array}$ & $\begin{array}{c}-4.394^{* *} \\
(2.46)\end{array}$ \\
\hline Labor & $\begin{array}{c}2.010 * * * \\
(3.32)\end{array}$ & $\begin{array}{c}3.896 * * * \\
(6.22)\end{array}$ & $\begin{array}{c}2.657 * * \\
(2.08)\end{array}$ & $\begin{array}{l}0.650 \\
(0.43)\end{array}$ & $\begin{array}{l}1.962 \\
(1.06)\end{array}$ \\
\hline Size & $\begin{array}{l}0.242 \\
(1.36)\end{array}$ & $\begin{array}{c}0.805 * * * \\
(6.63)\end{array}$ & $\begin{array}{c}0.935 * * * \\
(8.56)\end{array}$ & $\begin{array}{l}0.185 \\
(0.90)\end{array}$ & $\begin{array}{c}0.823^{* * *} \\
(3.83)\end{array}$ \\
\hline$R \& D$ & $\begin{array}{l}-0.760 \\
(0.82)\end{array}$ & $\begin{array}{l}8.905 \\
(0.98)\end{array}$ & $\begin{array}{l}9.076 \\
(1.10)\end{array}$ & $\begin{array}{c}33.828^{*} \\
(1.92)\end{array}$ & $\begin{array}{l}16.642 \\
(1.35)\end{array}$ \\
\hline Scale hor & $\begin{array}{l}-0.120 \\
(1.11)\end{array}$ & & $\begin{array}{l}-0.132 \\
(1.10)\end{array}$ & & \\
\hline Tariff_hor & $\begin{array}{l}0.026 \\
(0.29)\end{array}$ & $\begin{array}{l}-0.064 \\
(0.24)\end{array}$ & $\begin{array}{l}-0.048 \\
(0.25)\end{array}$ & & \\
\hline Tariff_ver & $\begin{array}{c}-0.160 * * \\
(2.18)\end{array}$ & & & & \\
\hline Tariff_plat & $\begin{array}{l}-0.138 \\
(0.38)\end{array}$ & & & & \\
\hline Constant & $\begin{array}{l}7.371 \\
(0.58)\end{array}$ & $\begin{array}{l}-22.465 \\
(1.10)\end{array}$ & $\begin{array}{c}-51.408 * * * \\
(3.09)\end{array}$ & $\begin{array}{c}-18.753^{*} \\
(1.73)\end{array}$ & $\begin{array}{l}19.744 \\
(0.89)\end{array}$ \\
\hline F-test excl. instruments & & $\begin{array}{c}60.20 \\
(0.000)\end{array}$ & $\begin{array}{c}14.38 \\
(0.000)\end{array}$ & $\begin{array}{c}9.49 \\
(0.006)\end{array}$ & $\begin{array}{l}147.72 \\
(0.000)\end{array}$ \\
\hline Wald test of exogenity & $\begin{array}{c}2.93 \\
(0.087)\end{array}$ & & & & \\
\hline Observations & 3221 & 69 & 64 & 28 & 53 \\
\hline
\end{tabular}

Note: F-test reports the F-statistic on the instrument from the first stage regression. Reported is also a Wald test of

exogenity of the instrumented variable. Standard errors clustered on country, t-statistics in parentheses, ${ }^{* * *}$ significant at one, $* *$ at five and * at ten percent level. 
Table 8. Interactions with firm characteristics

\begin{tabular}{|c|c|c|c|c|}
\hline \multirow[t]{2}{*}{ Dependent variable } & \multicolumn{2}{|c|}{ Total sales } & \multicolumn{2}{|c|}{ Total sales } \\
\hline & level & select & level & select \\
\hline Corruption & $\begin{array}{l}-2.218 \\
(1.28)\end{array}$ & $\begin{array}{c}-1.505^{* *} \\
(2.48)\end{array}$ & $\begin{array}{l}-0.971 \\
(1.01)\end{array}$ & $\begin{array}{c}-1.015^{* * * *} \\
(2.90)\end{array}$ \\
\hline Corruption*Size & $\begin{array}{l}0.236 \\
(0.97)\end{array}$ & $\begin{array}{l}0.110 \\
(1.35)\end{array}$ & & \\
\hline Corruption*R\&D & & & $\begin{array}{c}17.568 \\
(1.19)\end{array}$ & $\begin{array}{c}8.230 * * * \\
(3.22)\end{array}$ \\
\hline Size & $\begin{array}{c}0.601 * * * \\
(7.83)\end{array}$ & $\begin{array}{c}0.308 * * * \\
(9.33)\end{array}$ & $\begin{array}{c}0.656 * * * \\
(8.33)\end{array}$ & $\begin{array}{c}0.340 * * * \\
(13.36)\end{array}$ \\
\hline R\&D & $\begin{array}{r}-2.357 \\
(1.24)\end{array}$ & $\begin{array}{c}-3.337 * * * \\
(3.60)\end{array}$ & $\begin{array}{c}-6.597 * * \\
(2.16)\end{array}$ & $\begin{array}{c}-5.771 * * * \\
(3.93)\end{array}$ \\
\hline GDP/ capita & $\begin{array}{c}0.683 * * \\
(2.01)\end{array}$ & $\begin{array}{c}-0.102 \\
(0.86)\end{array}$ & $\begin{array}{c}0.639 * * \\
(1.98)\end{array}$ & $\begin{array}{r}-0.110 \\
(0.94)\end{array}$ \\
\hline GDP & $\begin{array}{c}0.549 * * * \\
(4.72)\end{array}$ & $\begin{array}{c}0.439 * * * \\
(11.50)\end{array}$ & $\begin{array}{c}0.534 * * * \\
(4.71)\end{array}$ & $\begin{array}{c}0.436 * * * \\
(11.75)\end{array}$ \\
\hline Market pot. & $\begin{array}{l}0.165 \\
(0.79)\end{array}$ & $\begin{array}{l}-0.010 \\
(0.08)\end{array}$ & $\begin{array}{l}0.144 \\
(0.72)\end{array}$ & $\begin{array}{l}-0.013 \\
(0.11)\end{array}$ \\
\hline Tax & $\begin{array}{l}0.763 \\
(1.23)\end{array}$ & $\begin{array}{c}0.444 * * \\
(2.04)\end{array}$ & $\begin{array}{l}0.759 \\
(1.26)\end{array}$ & $\begin{array}{c}0.452 * * \\
(2.11)\end{array}$ \\
\hline Distance & $\begin{array}{c}-0.528^{* *} \\
(2.48)\end{array}$ & $\begin{array}{c}-0.558 * * * \\
(5.61)\end{array}$ & $\begin{array}{c}-0.539 * * \\
(2.46)\end{array}$ & $\begin{array}{c}-0.568 * * * \\
(5.73)\end{array}$ \\
\hline Labor & $\begin{array}{l}0.078 \\
(0.15)\end{array}$ & $\begin{array}{r}-0.143 \\
(0.74)\end{array}$ & $\begin{array}{c}0.091 \\
(0.18)\end{array}$ & $\begin{array}{r}-0.150 \\
(0.78)\end{array}$ \\
\hline Scale hor & $\begin{array}{c}0.169 * * * \\
(2.97)\end{array}$ & $\begin{array}{c}-0.141 * * * \\
(4.52)\end{array}$ & $\begin{array}{c}0.167 * * * \\
(2.90)\end{array}$ & $\begin{array}{c}-0.141 * * * \\
(4.50)\end{array}$ \\
\hline Tariff hor & $\begin{array}{l}0.076 \\
(0.75)\end{array}$ & $\begin{array}{l}0.005 \\
(0.17)\end{array}$ & $\begin{array}{l}0.077 \\
(0.79)\end{array}$ & $\begin{array}{l}0.006 \\
(0.20)\end{array}$ \\
\hline Tariff ver & $\begin{array}{l}-0.117 \\
(0.94)\end{array}$ & $\begin{array}{c}-0.107^{* * * *} \\
(3.20)\end{array}$ & $\begin{array}{l}-0.116 \\
(0.93)\end{array}$ & $\begin{array}{c}-0.108 * * * \\
(3.29)\end{array}$ \\
\hline Tariff plat & $\begin{array}{l}-0.076 \\
(0.20)\end{array}$ & $\begin{array}{l}-0.082 \\
(0.42)\end{array}$ & $\begin{array}{l}-0.054 \\
(0.14)\end{array}$ & $\begin{array}{c}-0.076 \\
(0.38)\end{array}$ \\
\hline EPZ & $\begin{array}{l}0.212 \\
(1.05)\end{array}$ & $\begin{array}{c}-0.348^{* * * *} \\
(3.52)\end{array}$ & $\begin{array}{l}0.230 \\
(1.14)\end{array}$ & $\begin{array}{c}-0.350 * * * \\
(3.61)\end{array}$ \\
\hline Constant & $\begin{array}{c}-22.134 * * * \\
(4.44)\end{array}$ & $\begin{array}{c}-8.901^{* * *} \\
(4.32)\end{array}$ & $\begin{array}{c}-21.416^{* * * *} \\
(4.34)\end{array}$ & $\begin{array}{c}-8.777 * * * \\
(4.33)\end{array}$ \\
\hline Trade area dummies & yes & yes & yes & yes \\
\hline $\begin{array}{l}\text { Rho } \\
\text { Wald test of indep eq. } \\
\text { (rho=0) } \\
\text { Observations }\end{array}$ & 293 & $\begin{array}{c}0.40 \\
9.14 \\
(0.003) \\
6060\end{array}$ & 293 & $\begin{array}{c}0.39 \\
6.37 \\
(0.012) \\
6060\end{array}$ \\
\hline
\end{tabular}

Note: The Wald test of independent equations tests the hypothesis that rho $=0$. Standard errors clustered on country, ${ }^{* * *}$ significant at one, ${ }^{* *}$ at five and $*$ at ten percent level. 


\section{Appendix}

A.1. Variables and data sources

\begin{tabular}{|c|c|c|c|c|}
\hline Variable name & Definition & Source & $\begin{array}{l}\text { Cross- } \\
\text { section }\end{array}$ & Panel* \\
\hline Total sales & Total affiliate production (million USD) & RIIE & 1998 & A \\
\hline Local sales & $\begin{array}{l}\text { Total affiliate production-affiliate exports } \\
\text { (million USD) }\end{array}$ & RIIE & 1998 & A \\
\hline $\begin{array}{l}\text { Sales back to } \\
\text { home country }\end{array}$ & $\begin{array}{l}\text { Affiliate exports to Sweden (million } \\
\text { USD) }\end{array}$ & RIIE & 1998 & A \\
\hline $\begin{array}{l}\text { Sales to 3rd } \\
\text { country }\end{array}$ & $\begin{array}{l}\text { Affiliate exports to other countries than } \\
\text { Sweden (million USD) }\end{array}$ & RIIE & 1998 & A \\
\hline \multirow[t]{2}{*}{ Corruption } & $\begin{array}{l}\text { (6-ICRG index) } / 6 \text {, Scale of ICRG index: } \\
0-6\end{array}$ & $\begin{array}{l}\text { International } \\
\text { Country Risk } \\
\text { Group }\end{array}$ & 1998 & A \\
\hline & $(10-\mathrm{TI}$ index $) / 10$, Scale of TI index: $0-10$ & $\begin{array}{l}\text { Transparency } \\
\text { International }\end{array}$ & 1998 & N/A \\
\hline GDP / capita & $\ln ($ GDP per capita $)$ & WDI, World Bank & 1998 & A \\
\hline$G D P$ & $\ln (\mathrm{GDP})$ & WDI, World Bank & 1998 & A \\
\hline Market Pot. & $\begin{array}{l}\ln \left(\sum\left(\left(\mathrm{GDP}_{-}\{\mathrm{ij}\}\right) /(\text { distance })\right)\right) \text {, where } \\
\text { distance is the greater circle distance } \\
\text { between capitals between countries } \mathrm{i} \text { and } \\
\mathrm{j} \text {. }\end{array}$ & $\begin{array}{l}\text { PennWorld } \\
\text { Tables } 6\end{array}$ & 1998 & A \\
\hline $\operatorname{Tax}$ & $\ln ($ average corporate tax rate on profits) & $\begin{array}{l}\text { PricewaterhouseCo } \\
\text { opers }\end{array}$ & 1998 & N/A \\
\hline Distance & $\begin{array}{l}\text { In(the greater circle distance between } \\
\text { capitals in kilometers) }\end{array}$ & $\begin{array}{l}\text { PennWorld } \\
\text { Tables } 6\end{array}$ & & A \\
\hline Labor & $\begin{array}{l}\ln \text { (share of population aged } 25 \text { and over } \\
\text { attained primary or secondary education) }\end{array}$ & $\begin{array}{l}\text { Barro and Lee } \\
(2000)\end{array}$ & 1999 & N/A \\
\hline Size & $\ln ($ total corporate sales million USD) & RIIE & 1998 & A \\
\hline$R \& D$ & $\ln (1+((\mathrm{R} \& \mathrm{D}$ expenditure $) /($ sales $)))$ & RIIE & 1998 & A \\
\hline Scale & $\begin{array}{l}\text { ln(average plant sales in four-digit } \\
\text { industry million USD ) }\end{array}$ & Statistics Sweden & 1998 & N/A \\
\hline Tariff_hor & $\begin{array}{l}\ln \text { (industry average tariffs on exports } \\
\text { from Sweden to the host country) }\end{array}$ & Haveman & 1998 & N/A \\
\hline Tariff_ver & $\begin{array}{l}\ln (\text { industry average tariffs on exports } \\
\text { from the host country) }\end{array}$ & Haveman & 1998 & N/A \\
\hline Tariff_plat & $\begin{array}{l}\ln \text { (industry average tariffs on exports } \\
\text { from the host country to other countries) }\end{array}$ & Haveman & 1998 & N/A \\
\hline Time & $\begin{array}{l}\ln (\text { number of business days it takes to } \\
\text { obtain legal status to operate a firm), } \\
1999\end{array}$ & $\begin{array}{l}\text { Djankov et al. } \\
(2002)\end{array}$ & 1999 & N/A \\
\hline Invest risk & $\begin{array}{l}\text { (4-risk index) } / 4 \text {, Scale of ICRG index: 0- } \\
6\end{array}$ & $\begin{array}{l}\text { International } \\
\text { Country Risk } \\
\text { Group }\end{array}$ & 1998 & A \\
\hline Wage_costs & $\ln$ (average hourly wage of a toolmaker) & UBS & 1997 & $\begin{array}{l}1985(1986), 1991 \\
(1990), 1994(1994), \\
1997(1998), 2003 \\
(2003)^{* *}\end{array}$ \\
\hline
\end{tabular}




\begin{tabular}{|c|c|c|c|}
\hline$E P Z$ & $\begin{array}{l}\text { One if country has export processing } \\
\text { zones, zero otherwise }\end{array}$ & $\begin{array}{l}\text { ILO database on } \\
\text { export processing } \\
\text { zones }\end{array}$ & $\mathrm{N} / \mathrm{A}$ \\
\hline Mortality & European settler mortality rates. & $\begin{array}{l}\text { Acemoglu et al } \\
(2001)\end{array}$ & \\
\hline Protestant & $\begin{array}{l}\text { Percent of population professing } \\
\text { Protestant faith } 1980 \text {. }\end{array}$ & $\begin{array}{l}\text { Taken from Treisman (2000). } \\
\text { et al (1999) and Barett (1982) }\end{array}$ & Driginal source La Porta \\
\hline Democracy & $\begin{array}{l}\text { The country has been a democracy since } \\
1950 \text {. }\end{array}$ & $\begin{array}{l}\text { Taken from Treisman (2000). } \\
\text { et al (1996) }\end{array}$ & Driginal source Alvarez \\
\hline
\end{tabular}

Note: * $A=$ Available, $N / A=$ Not Available.** Data for the year in front of brackets is used for the year in brackets. All monetary variables are in dollars if not otherwise stated. 
A.2. Summary statistics

\begin{tabular}{|c|c|c|c|c|c|}
\hline Variable & Obs & Mean & Std. Dev. & Min & Max \\
\hline Total sales & 325 & 109.37 & 435.96 & $1.258 \mathrm{E}-04$ & 5388.19 \\
\hline Local sales & 325 & 60.99 & 297.22 & 0 & 4725.81 \\
\hline $\begin{array}{l}\text { Sales back to } \\
\text { home country }\end{array}$ & 344 & 10.87 & 152.88 & 0 & 2834.63 \\
\hline $\begin{array}{l}\text { Sales to 3rd } \\
\text { country }\end{array}$ & 342 & 36.42 & 129.78 & 0 & 1322.41 \\
\hline Corruption & 357 & 0.26 & 0.20 & 0 & 0.79 \\
\hline GDP/Cap & 368 & 18785.79 & 8282.21 & 470.00 & 40640.00 \\
\hline$G D P$ & 369 & $1.29 \mathrm{E}+12$ & $2.25 \mathrm{E}+12$ & $6.72 \mathrm{E}+08$ & $8.72 \mathrm{E}+12$ \\
\hline Market Pot. & 365 & 10921.33 & 5262.74 & 2242.05 & 22093.47 \\
\hline $\operatorname{Tax}$ & 366 & 32.46 & 5.33 & 15 & 45 \\
\hline Distance & 367 & 3124.12 & 3436.65 & 379.22 & 15600.58 \\
\hline Labor & 344 & 36.80 & 10.98 & 5.20 & 62.80 \\
\hline Size & 374 & 4189.88 & 6824.58 & 5.36 & 28051.27 \\
\hline$R \& D$ & 374 & 0.02 & 0.03 & 0 & 0.26 \\
\hline Scale hor & 374 & 121.40 & 227.20 & 0.85 & 1146.02 \\
\hline Tariff hor & 347 & -0.99 & 2.06 & -2.30 & 3.79 \\
\hline Tariff ver & 363 & -1.12 & 1.65 & -2.30 & 2.52 \\
\hline Tariff plat & 362 & 2.54 & 0.32 & 1.71 & 3.16 \\
\hline Time & 357 & 36.42 & 26.50 & 2.00 & 128.00 \\
\hline Invest risk & 356 & 0.26 & 0.12 & 0.08 & 0.94 \\
\hline Wage cost & 348 & 28.64 & 14.62 & 1.77 & 54.75 \\
\hline
\end{tabular}

Note: All value variables are in USD. Corruption and invest risk measures are in normalized form as given in Table A1. Includes all observations with production in 1998. 


\section{A.3. Correlation table.}

\begin{tabular}{|c|c|c|c|c|c|c|c|c|c|c|c|c|c|c|c|c|c|c|c|c|}
\hline Var- & (1) & $(2)$ & (3) & (4) & (5) & $(6)$ & $(7)$ & $(8)$ & (9) & $(10)$ & $(11)$ & (12) & $(13)$ & $(14)$ & $(15)$ & $(16)$ & $(17)$ & (18) & $(19)$ & $(20)$ \\
\hline iable & $\begin{array}{l}\text { Total } \\
\text { sales }\end{array}$ & $\begin{array}{l}\text { Local } \\
\text { sales }\end{array}$ & $\begin{array}{l}\text { Sales } \\
\text { back to } \\
\text { home } \\
\text { country }\end{array}$ & $\begin{array}{l}\text { Sales } \\
\text { to 3rd } \\
\text { country }\end{array}$ & $\begin{array}{l}\text { Corrup- } \\
\text { tion }\end{array}$ & $\begin{array}{l}G D P / \\
\text { Cap }\end{array}$ & $G D P$ & $\begin{array}{l}\text { Market } \\
\text { Pot. }\end{array}$ & Tax & $\begin{array}{l}\text { Dist- } \\
\text { ance }\end{array}$ & Labor & Size & $R \& D$ & $\begin{array}{l}\text { Scale } \\
\text { hor }\end{array}$ & $\begin{array}{l}\text { Tariff } \\
\text { hor }\end{array}$ & $\begin{array}{l}\text { Tariff } \\
\text { ver }\end{array}$ & $\begin{array}{l}\text { Tariff } \\
\text { plat }\end{array}$ & Time & $\begin{array}{l}\text { Invest } \\
\text { risk }\end{array}$ & $\begin{array}{l}\text { Wage } \\
\text { cost }\end{array}$ \\
\hline
\end{tabular}

\begin{tabular}{|c|c|c|c|c|c|c|c|c|c|c|c|c|c|c|c|c|c|c|c|c|}
\hline (1) & 1.000 & & & & & & & & & & & & & & & & & & & \\
\hline (2) & 0.822 & 1.000 & & & & & & & & & & & & & & & & & & \\
\hline (3) & 0.554 & 0.030 & 1.000 & & & & & & & & & & & & & & & & & \\
\hline (4) & 0.815 & 0.463 & 0.569 & 1.000 & & & & & & & & & & & & & & & & \\
\hline (5) & 0.069 & 0.054 & 0.073 & 0.033 & 1.000 & & & & & & & & & & & & & & & \\
\hline (6) & 0.125 & 0.125 & 0.030 & 0.106 & -0.462 & 1.000 & & & & & & & & & & & & & & \\
\hline (7) & 0.204 & 0.293 & -0.026 & 0.072 & 0.169 & 0.458 & 1.000 & & & & & & & & & & & & & \\
\hline (8) & -0.036 & -0.148 & 0.123 & 0.067 & -0.474 & 0.320 & -0.431 & 1.000 & & & & & & & & & & & & \\
\hline (9) & 0.041 & -0.001 & 0.071 & 0.064 & -0.042 & 0.273 & 0.097 & 0.306 & 1.000 & & & & & & & & & & & \\
\hline (10) & 0.052 & 0.109 & -0.037 & -0.020 & 0.573 & -0.332 & 0.261 & -0.762 & -0.179 & 1.000 & & & & & & & & & & \\
\hline (11) & -0.136 & -0.141 & -0.030 & -0.110 & -0.521 & 0.108 & -0.382 & 0.387 & 0.105 & -0.549 & 1.000 & & & & & & & & & \\
\hline (12) & 0.361 & 0.255 & 0.208 & 0.394 & 0.105 & -0.149 & -0.088 & -0.102 & -0.007 & 0.184 & -0.042 & 1.000 & & & & & & & & \\
\hline (13) & 0.029 & -0.001 & 0.055 & 0.037 & 0.094 & -0.067 & 0.049 & -0.080 & 0.048 & 0.083 & 0.002 & 0.164 & 1.000 & & & & & & & \\
\hline (14) & 0.211 & 0.103 & 0.181 & 0.269 & 0.010 & -0.040 & -0.041 & -0.007 & 0.051 & 0.060 & -0.055 & 0.431 & 0.019 & 1.000 & & & & & & \\
\hline (15) & 0.056 & 0.118 & -0.041 & -0.021 & 0.563 & -0.516 & 0.208 & -0.691 & -0.229 & 0.814 & -0.509 & 0.248 & 0.121 & 0.108 & 1.000 & & & & & \\
\hline (16) & 0.054 & 0.124 & -0.045 & -0.032 & 0.402 & -0.069 & 0.385 & -0.637 & -0.032 & 0.714 & -0.355 & 0.172 & 0.053 & 0.065 & 0.694 & 1.000 & & & & \\
\hline (17) & -0.060 & -0.136 & 0.078 & 0.015 & -0.211 & -0.089 & -0.199 & 0.085 & -0.134 & -0.124 & 0.275 & 0.118 & -0.110 & -0.044 & -0.021 & 0.027 & 1.000 & & & \\
\hline (18) & -0.058 & -0.078 & -0.006 & -0.013 & 0.498 & -0.722 & -0.314 & -0.228 & -0.101 & 0.117 & -0.155 & 0.064 & 0.038 & -0.011 & 0.245 & -0.110 & -0.011 & 1.000 & & \\
\hline (19) & -0.042 & -0.039 & -0.007 & -0.040 & 0.509 & -0.260 & -0.128 & -0.324 & -0.112 & 0.457 & -0.192 & 0.172 & 0.012 & 0.050 & 0.501 & 0.465 & -0.059 & 0.127 & 1.000 & \\
\hline (20) & 0.095 & 0.080 & 0.041 & 0.089 & -0.405 & 0.892 & 0.337 & 0.318 & 0.167 & -0.292 & 0.118 & -0.114 & -0.070 & -0.032 & -0.444 & -0.041 & -0.060 & -0.740 & 0.021 & 1.000 \\
\hline
\end{tabular}

Note: Corruption and invest risk measures are in normalized form as given in Table A1. Includes observations for the 1998 sample (276 obs). 